\title{
Future Climate Change in the Baltic Sea Region and Environmental Impacts
}

\section{Räisänen, Jouni Antero}

Oxford University Press

2017-10

Räisänen , J A 2017 , Future Climate Change in the Baltic Sea Region and Environmental Impacts . in H V Storch (ed.), Oxford Research Encyclopedias : Climate Science . Oxford University Press , Oxford . https://doi.org/10.1093/acrefore/9780190228620.013.634

http://hdl.handle.net/10138/310791

https://doi.org/10.1093/acrefore/9780190228620.013.634

unspecified

acceptedVersion

Downloaded from Helda, University of Helsinki institutional repository.

This is an electronic reprint of the original article.

This reprint may differ from the original in pagination and typographic detail.

Please cite the original version. 


\section{Future climate change in the Baltic Sea region and}

2 environmental impacts

4 Jouni Räisänen

5 Department of Physics, University of Helsinki

6

\section{Summary and keywords}

8 The warming of the global climate is expected to continue in this century although

9 the magnitude of change depends on future anthropogenic greenhouse gas

10 emissions and the sensitivity of climate to them. The regional characteristics and

11 impacts of future climate change in the Baltic Sea countries have been explored

12 since at least the 1990s. Later research has supported many findings from these

13 early studies, but advances in understanding and improved modelling tools have

14 made the picture gradually more comprehensive and more detailed. Nevertheless,

15 many uncertainties still remain.

16

17 In the Baltic Sea region, warming is likely to exceed its global average,

18 particularly in winter and in the northern parts of the area. The warming is

19 accompanied by a general increase in winter precipitation, but in summer

20 precipitation may either increase or decrease, with a larger chance of drying in the

21 southern than in the northern parts of the region. Despite the increase in winter

22 precipitation, the amount of snow is generally expected to decrease, because a

23 smaller fraction of the precipitation falls as snow and mid-winter snow melt

24 episodes become more common. Changes in windiness are very uncertain, 
25 although most projections suggest a slight increase in average wind speed over the

26 Baltic Sea. Climatic extremes are also projected to change, but some of their

27 changes will differ from the corresponding change in mean climate. For example,

28 the lowest winter temperatures are expected to warm even more than the winter

29 mean temperature, and short-term summer precipitation extremes are likely to

30 become more severe even in those areas where the mean summer precipitation

31 does not increase.

33 The projected atmospheric changes are accompanied by an increase in Baltic Sea

34 water temperature, reduced ice cover, and, according to most studies, reduced

35 salinity due to increased precipitation and river runoff. The seasonal cycle of

36 runoff is modified by changes in precipitation and earlier snowmelt. Global-scale

37 sea level rise also affects the Baltic Sea, but is counteracted by glacial isostatic

38 adjustment. In the northern parts of the Baltic Sea, the latter will still dominate

39 according to most projections, leading to a continued although decelerated

40 decrease in relative sea level. These changes in the physical environment and

41 climate will have a number of environmental impacts; for example, related to

42 atmospheric chemistry, freshwater and marine biogeochemistry, ecosystems, and

43 coastal erosion. However, future environmental change in the region will be

44 affected by several interrelated factors. Climate change is only one of them, and in

45 many cases its effects may be exceeded by other anthropogenic changes.

47 KEYWORDS: Climate change, Climate change projection, Baltic Sea, Baltic Sea 48 basin, Northern Europe, Climate change impacts 


\section{Introduction}

52 During the last few decades, it has become increasingly clear that humans are

53 affecting the global climate. The global mean temperature has increased by nearly

$54 \quad 1^{\circ} \mathrm{C}$ since the late $19^{\text {th }}$ century, and anthropogenic emissions of carbon dioxide

$55\left(\mathrm{CO}_{2}\right)$ and other greenhouse gases have been identified as the main culprit

56 (Bindoff et al., 2013). Much larger climate changes might occur during this

57 century and beyond, particularly if ongoing political efforts to reduce greenhouse

58 gas emissions are not succesful.

60 Since climate widely affects the natural environment and human activities,

61 adaptation to changing climate will be needed. To help the adaptation,

62 information on the possible characteristics of the future climate change and on the

63 sensitivity of natural and human systems to this change is required. This article

64 outlines the current knowledge on future climate change for the Baltic Sea and its

65 drainage basin in northern Europe. The potential environmental impacts of

66 climate change in the area also discussed, although in less depth than climate

67 change itself.

69 The Baltic Sea is a large semi-enclosed brackish water estuary adjoining the 70 northeastern Atlantic Ocean, with an area of $415000 \mathrm{~km}^{2}$ with Kattegat included.

71 Its drainage basin covers 1.7 million square kilometres and hosts 85 million

72 people in 14 countries (HELCOM, 2015). Given this large population, it is 73 unsurprising that climate change is not the only environmental issue in the area. In

74 particular, the ecological state of the Baltic Sea has been severely degraded by 75 water- and airbone nutrient loads and other pollution from the surrounding land 
76 areas. This far, the environmental effects of climate change have been in many

77 cases secondary to these direct anthropogenic impacts. Similarly, the question on

78 how the environment in the Baltic Sea region will change in the future is much

79 wider than how it will be affected by climate change alone. Nevertheless, climate

80 change already represents an additional stress factor for many natural systems

81 which is likely to become more important in the future.

83 This article first discusses the historical background of climate change research

84 for the Baltic Sea area, outlines the modelling tools and scenarios used for

85 constructing projections of future climate change, and puts the climate changes

86 projected for the Baltic Sea region in a global perspective. After this, climate

87 change in the Baltic Sea basin is discussed in more detail, covering various

88 aspects of the atmospheric climate, snow conditions, hydrology, and the ocean

89 climate in the Baltic Sea itself. Third, the potential environmental impacts of

90 climate change are explored. For the environmental impacts, in particular, this text

91 only scratches the surface of a very wide and complicated topic. Many of the

92 issues introduced in this article have been discussed in more depth in the first

93 (BACC Author Team, 2008) and the second (BACC II Author Team, 2015)

94 climate change assessments for the Baltic Sea basin.

95

\section{Historical context}

97 The possibility that changes in atmospheric $\mathrm{CO}_{2}$ concentration could affect the

98 global climate was already raised in the $19^{\text {th }}$ century (Arrhenius, 1896).

99 Measurements started in 1958 by Charles Keeling at Mauna Loa in Havaii showed

100 that the $\mathrm{CO}_{2}$ concentration was actually increasing, which is now convincingly 
101 ascribed to human activities, mainly fossil fuel burning (Watson, Rodhe,

102 Oeschger \& Siegenthaler, 1990; Ciais et al., 2013). Finally, in 1995, comparison

103 between climate model simulations and observed temperature changes allowed

104 the Intergovernmental Panel on Climate Change (IPCC) to declare that „The

105 balance of evidence suggests a discernible human influence on global climate"

106 (IPCC 1996, p. 4) - a conclusion that has been substantially strengthened by later

107 research. These facts raise two important questions. First, how will climate change

108 in the future, and second, how will this change affect humans and the natural

109 environment?

111 Climate will not change in the same way in all parts of the world. Although more

112 or less all areas are expected to become warmer, the magnitude of the warming

113 will vary. For other variables such as precipitation, even the sign of the change

114 will differ between regions. Estimates on the regional distribution of future

115 climate changes have been available from three-dimesional global climate models

116 (CCMs) since the 1980s (e.g., Stouffer, Manabe \& Bryan, 1989).

118 The first GCMs were still very coarse-grained and their results thus allowed only

119 broad and tentative conclusions about the regional distribution of climate changes.

120 Nevertheless, many of these conclusions have stood the challenge of time. For

121 example, the models available for the first IPCC assessment consistently indicated

122 a greater than global average warming at high northern latitudes in winter, and

123 increases in precipitation at high latitudes throughout the year and at midlatitudes

124 in winter (Mitchell, Manabe, Meleshko \& Tokioka, 1990, p. 135). Since then,

125 climate models have become much more sophisticated, with many more processes

126 included and finer horizontal resolution. The number of models developed in 
127 different research institutions around the world has also greatly increased. 128 Nonetheless, the models used in the IPCC fifth assessment still nearly 129 unanimously agreed on these large-scale features of temperature and precipitation 130 change (Collins et al., 2013, p. 1059 and 1078).

132 Regional studies that specifically explored potential future climate change in areas 133 close to the Baltic Sea region also began to appear in the 1990s. In the first multi134 GCM study for northern Europe, Räisänen (1994) used four GCMs forced with a 135 gradual doubling of atmospheric $\mathrm{CO}_{2}$. He found the average simulated winter 136 warming in Finland to be $3-4^{\circ} \mathrm{C}$, whereas the warming in summer was slightly

137 over $2^{\circ} \mathrm{C}$. Because these simulations were based on a highly idealized forcing 138 scenario, their results are not directly applicable to the real world. However, 139 similar idealized GCM experiments conducted in the early 2010s still largely 140 reproduced these early results, although with a tendency towards slightly larger

141 summer warming (Räisänen \& Ylhäisi, 2015).

143 The realization that climate was changing and might change much more during 144 the next hundred years soon stimulated a surge of research on the impacts of 145 climate change. An early national example was the Finnish Research Programme 146 on Climate Change (SILMU; Kämäri, 1997) which explored the potential effects 147 of climate change on Finnish forests, peatlands, agriculture, inland waters and the 148 Baltic Sea. Guided by the GCM results available at that time, three idealized 149 scenarios of climate change were formulated for the impact assessment (Carter, 150 Posch \& Tuomenvirta, 1996). These scenarios assumed a linear 0.1 to $0.6^{\circ} \mathrm{C}$ per 151 decade increase in the annual mean temperature and a 0.25 to $1.5 \%$ per decade 152 increase in annual precipitation throughout the 21st century, with larger changes 
153 in winter than in summer in both of these variables. Another early example of

154 impact research was the Climate Change and Energy Production project

155 (Sælthun, 1992; Sælthun et al. 1998), which assessed the hydrological effects of

156 climate change in the Nordic countries with a special emphasis on hydropower

157 projection, using temperature and precipitation change scenarios formulated by

158 Jóhannesson, Jónsson, Källén \& Kaas (1995).

160 Nevertheless, the coarse resolution of GCMs (of the order of $500 \mathrm{~km}$ in the 1990s)

161 was perceived as a serious limitation for regional climate change studies. At such

162 a resolution, geographical features such as the Scandinavian mountains and the

163 Baltic Sea were at best marginally present in the GCMs. This motivated the

164 development of higher-resolution regional climate models (RCMs). By the end of 165 the 1990s, four countries in the Baltic Sea region - Sweden (Rummukainen et al., 166 2000), Norway (Bjørge \& Haugen, 1998), Denmark (Christensen, Christensen, 167 Machenhauer \& Botzet, 1998) and Germany (Jacob and Podzun, 1997) - had 168 established their own regional climate modelling programs. Christensen et al. 169 (2001) provided the first multi-RCM intercomparison of climate change 170 simulations for the Scandinavian region. In the next decade, RCM simulations for 171 the European area were conducted in a coordinated manner within the

172 PRUDENCE (Christensen, Carter \& Rummukainen, 2007) and ENSEMBLES

173 (van der Linden \& Mitchell, 2009) projects. In the 2010's, an ensemble of very

174 high-resolution $(12.5 \mathrm{~km}) \mathrm{RCM}$ simulations for Europe has been produced under 175 the EURO-CORDEX initiative (Jacob et al., 2014).

177 Research on climate change and its impacts has been done in all Baltic Sea 178 countries. To collect the pieces together, an international team of authors 
179 compiled in 2008 the first Assessment of Climate Change for the Baltic Sea Basin

180 (BACC Author Team, 2008). Seven years later, an update was published (BACC

181 II Author Team, 2015) to take advantage of the new knowledge gathered since the

182 first assessment. The two BACC assessements are comprehensive in scope,

183 covering both past and potential future climate changes in the Baltic Sea region

184 and the environmental impacts of these changes. In the second assessment, some

185 of the potential socio-economical impacts of climate change are also discussed.

\section{Models and scenarios}

188 It might seem tempting to predict future climate change simply by extrapolating

189 observed trends. However, such extrapolation would only make sense if past and

190 future climate changes had exactly the same causes. In reality, anthropogenic

191 climate change is the net effect of several factors - for example, changes in the

192 concenrtations of $\mathrm{CO}_{2}$ and other greenhouse gases, atmospheric aerosols and land

193 use - and the balance between them might differ between the past and the future.

194 Moreover, climate exhibits substantial natural variability - temperature,

195 precipitation and other climate variables vary from year to year and from decade

196 to decade, regardless of what humans are doing. Thus, climate changes, for

197 example, during the past half-century represent a combination of anthropogenic 198 change and natural variability, but it is often difficult to separate these

199 contributions from each other. Similarly, future climate changes will result from a

200 combination of anthropogenic change and natural variability, but it is not known

201 whether the natural variations will oppose or reinforce the anthropogogenic 202 changes. 
204 The main tool for constructing projections of future global and continental scale

205 climate change are global climate models (GCMs). These models are built on

206 basic physical principles such as conservation of mass, momentum and energy

207 that govern the behaviour of the atmosphere and the oceans. As input, a GCM

208 needs information on such "external" factors that it cannot predict itself. This

209 includes, for example, either the anthropogenic emissions or concentrations of

$210 \mathrm{CO}_{2}$ and other greenhouse gases. In addition, the initial conditions of the

211 simulation (that is, the state of the atmosphere, oceans, sea ice and land surface in

212 the beginning of the model experiment) are needed. However, after the external

213 factors and the initial conditions have been specified, the model simulation is self-

214 contained. Thus, no information on observed climate changes is used when

215 simulating future climate change with GCMs.

217 GCMs simulate the evolution of atmospheric weather in a global three218 dimensional network of grid points, with a time step of tens of minutes. Their 219 output thus includes time series of temperature, winds and and other weather 220 parameters all around the world, not only near the surface but also higher up in the 221 atmosphere. Obviously, however, the detailed daily or even year-to-year evolution

222 of weather cannot be predicted decades in advance. What the models attempt to 223 predict is climate, that is, the long-term mean values and other statistical 224 properties of weather. In such long-term statistics, the effects of unpredictable 225 shorter-term variability are greatly reduced, although they still remain non226 negligible even in multi-decadal averages (Erikssson, Omstedt, Overland, Percival 227 \& Mofjeld, 2007; Deser, Phillips, Bourdette \& Teng, 2012). 
229 A major limitation in GCMs is their relatively coarse resolution that is necessary

230 to keep the need of computing resources manageable. The CMIP5 generation of 231 models used in the 2010s (Taylor et al. 2012) typically had horizontal grid

232 spacings of $100-250 \mathrm{~km}$, whereas the earlier models were even coarser. This is a

233 limitation in simulating regional climate and climate change, particularly as the

234 skilful scale of GCMs is several times larger than their nominal grid scale (Grotch $235 \&$ MacCracken, 1991).

237 Regional climate models (RCMs) have higher spatial resolution than GCMs 238 (typically 10-50 km) but cover a limited geographic area, a few thousands of 239 kilometres arcross. They therefore need boundary conditions that specify the time240 evolving atmospheric state at their horizontal boundaries. In climate change 241 projection, the boundary conditions are derived from GCM simulations. Thus, 242 climate changes in a RCM simulation depend on the driving GCM as well as the 243 RCM itself (Déqué et al, 2012). Nevertheless, the higher resolution of RCMs 244 compared with GCMs allows a better description of geographic features such as 245 mountain ranges and the land-sea distribution that affect the regional climate. Due 246 to their higher resolution, the RCMs also better resolve the details of atmospheric 247 weather systems, which enhances the simulation of extremes such as storms and 248 heavy precipitation.

249 Another technique for constructing scenarios of future climate on small scales is 250 statistical downscaling. In this case, observed statistical relationships between the 251 large-scale atmospheric state and the local conditions are combined with either 252 GCM or RCM simulations of larger-scale climate, to infer what these large-scale 253 conditions would imply on the local scale. With statistical downscaling, scenarios 254 can be constructed for truly local conditions, below the scale resolved by RCMs. 
255 On the other hand, statistical downscaling relies strongly on the assumption that 256 the relationship between the large-scale and local conditions remains unchanged

257 despite climate change (Wibig et al., 2015; Benestad, 2016).

259 A complication in both GCM- and RCM-based studies of future climate are model

260 biases, that is, differences between the simulated and observed present-day 261 climate. Even in state-of-the-art RCM simulations, the biases in temperature may 262 reach several ${ }^{\circ} \mathrm{C}$, and precipitation biases of several tens of per cent are common

263 (Wibig et al., 2015). In the ideal case that these biases remain similar in the 264 simulation of future climate, they have no large effect on the simulated 265 temperature and precipitation changes. Nevertheless, such biases generally 266 preclude the direct use of RCM output in, for example, hydrological models, 267 without some form of statistical adjustments (Graham, Andréasson \& Carlsson, 268 2007; Räty, Virta, Bosshard, \& Connelly 2017). Because there is no unique 269 "correct" method for doing these adjustments, this intermediate step introduces 270 additional uncertainties to the projection of (e.g.) river runoff and consequently 271 Baltic Sea salinity.

273 In general, the word projection is preferred over prediction when referring to 274 model simulations of future climate change. This is because these projections are 275 conditional on the evolution of greenhouse gas emissions and other anthropogenic 276 forcing. This evolution becomes naturally increasingly uncertain with increasing 277 time horizon. To cope with this uncertainty, emission or forcing scenarios are 278 constructed using different but internally consistent assumptions. During the $21^{\text {st }}$ 279 century, two sets of scenarios have been widely used for climate projection: the 280 SRES (Special Report on Emissions Scenarios; Nakićenović and Swart, 2000) and 
281 the RCP (Representative Concentration Pathways; van Vuuren et al., 2011)

282 scenarios. These scenarios cover a wide range of $\mathrm{CO}_{2}$ emissions and

283 concentrations (Fig. 1), but nearly all of them indicate a monotonic increase in

$284 \mathrm{CO}_{2}$ concentration at least until the end of this century. The only exception is

285 RCP2.6, in which a deep decline of $\mathrm{CO}_{2}$ emissions leads to a slow decrease of the

$286 \mathrm{CO}_{2}$ concentration in the second half of the century. In addition to $\mathrm{CO}_{2}$, other 287 greenhouse gases, anthropogenic aerosols and land use change are also included 288 in the SRES and RCP scenarios.

\section{Global perspective on future climate change}

290 The warming of the global climate is projected to continue in this century, but the

291 magnitude of the change is uncertain (Fig. 2). The choice between different RCP

292 (or SRES) scenarios has only a moderate effect in the next few decades, but

293 becomes the dominating source of uncertainty by the end of the century (see also

294 Hawkins \& Sutton, 2009). However, the projections from different GCMs also 295 differ from each other. For the ensemble of models in Fig. 2, the changes in global 296 mean temperature from the years $1986-2005$ to $2081-2100$ vary from 0 to $2{ }^{\circ} \mathrm{C}$ 297 under the lowest (2.6) and from 2.5 to $5^{\circ} \mathrm{C}$ under the highest (8.5) RCP scenario.

299 Two factors contribute to the inter-GCM differences in climate change under the 300 same forcing scenario (Collins et al., 2013). First, there are genuine differences in 301 the response of the models to external forcing such as increases in greenhouse gas 302 concentrations, as well as subtle differences in the implementation of the 303 scenarios. Second, there is unforced natural variability in the simulated climate.

304 This stochastic variability is a very minor source of uncertainty in multi-decadal 305 to centennial projections of the global mean temperature. However, it is more 
306 important for climate change on regional and local scales, particularly for

307 variables such as precipitation or wind speed (Hawkins \& Sutton, 2011; Pryor \&

308 Barthelmie, 2010). Such unforced variability also occurs in the real world and sets

309 an upper limit for the predictability of future climate. In some cases, this

310 variability may be strong enough to dominate over the effects of anthropogenic

311 climate change throughout the $21^{\text {st }}$ century (Maraun, 2013).

313 The projected warming is generally larger over land than sea and over high than

314 low latitudes (Collins et al., 2013). It is thus unsuprising that most GCMs project

315 the annual mean warming in the Baltic Sea region to exceed the global average

316 (Fig. 3). The warming in the Baltic Sea region tends to increase with increasing

317 global mean warming, but the correlation is not one-to-one. In some models, the

318 regional warming is twice the global mean. However, there are also a few model

319 simulations in which the Baltic Sea region warms less than the world on the

320 average, or even becomes colder. When present in GCM simulations, cooling in

321 the Baltic Sea region adjoins larger cooling over the northern North Atlantic (e.g.,

322 model FIO-ESM in Fig. 12.9 of Collins et al., 2013). It is not clear whether such a

323 dramatic outcome is a real although unlikely possibility or results from a

324 deficiency in some specific GCMs. Although many GCMs simulate some local

325 cooling over parts of the northern North Atlantic, due to reduced northward heat

326 transport by the ocean circulation, this cooling only rarely extends over the

327 surrounding land areas (Collins et al., 2013, Fig. 12.9). 


\section{Projected climate change in the Baltic Sea region}

\section{Temperature}

331 Most GCMs project a very large warming over the Arctic Ocean in late fall and

332 winter, due to increased ocean-to-atmosphere heat flux through reduced ice cover

333 and other amplifying feedbacks (Collins et al., 2013). This strong warming

334 extends in a muted form to the Baltic Sea region, particularly its northern parts

335 (Fig. 4a). The warming in summer is weaker but nonetheless exceeds the global 336 average in most GCMs (Fig. 4c; Räisänen \& Ylhäisi, 2015). Projections from

337 RCMs agree with this large-scale pattern (Christensen, Kjellström \& Zorita,

338 2015). However, the intermodel variation of both the GCM and the RCM

339 projections is substantial even for the same emissions scenario (Fig. 4e; Fig. 11.3

340 in Christensen et al., 2015), although some warming occurs in nearly all of the

341 projections.

343 The warming in winter will likely be accompanied by a decrease in temperature

344 variability, both on daily and interannual time scales (Räisänen, 2002; Räisänen et

345 al., 2004; Kjellström et al., 2007; Nikulin et al., 2011; Ylhäisi \& Räisänen, 2014).

346 This decrease is partly connected to the geographical distribution of the projected 347 temperature changes (Holmes, Woollings, Hawkins \& de Vries, 2016). Larger

348 warming over the Arctic Ocean and northern Eurasia than over the northern North

349 Atlantic reduces the time mean temperature gradient, making temperatures less

350 sensitive to variations of the atmospheric circulation. As a result, the lowest

351 winter temperatures are projected to increase even more than the winter mean 352 temperature. In summer, the variability might either slightly increase or remain at 353 its current level. Both GCM and RCM simulations support increased temperature 
354 variability in summer in central Europe (Räisänen et al., 2004; Kjellström et al., 355 2007; Nikulin et al., 2011; Ylhäisi \& Räisänen, 2014; Holmes et al., 2016), but the

356 signal is far less clear further north in the Baltic Sea region. Even if the variability

357 remains at its current level, periods of hot weather are expected to become more

358 severe and more common following the increase in the summer mean temperature

359 (Nikulin et al., 2011).

\section{Precipitation}

361 On the large scale, precipitation is projected to increase in high northern latitudes.

362 This is both due to increased northward moisture transport in the atrmosphere

363 (which is mainly caused by the larger moisture content of warmer air but is also

364 affected by changes in atmospheric circulation) and increased moisture supply

365 from local evaporation (Held \& Soden, 2006; Collins et al., 2013). Conversely,

366 precipitation is projected to decrease in many subtropical and lower-midlatitude

367 areas, including the Mediterranean region. However, the transition between

368 increasing and decreasing precipitation occurs further north in summer than in

369 winter. For the Baltic Sea basin, this suggests a general increase in precipitation in

370 winter (Fig. 4b). In summer, precipitation may either increase or decrease, with a

371 larger chance of drying in the southern than in the northern parts of the region

372 (Fig. 4d).

374 Projections of precipitation change are less robust than those of temperature 375 change, varying widely between different GCMs and RCMs (Fig. 4f; Fig. 11.5 in

376 Christensen et al., 2015). This reflects, in part, the large natural variability of

377 precipitation - in comparison with this variability, the projected anthropogenic

378 precipitation changes are smaller than the changes in temperature (Räisänen \& 
379 Ruokolainen, 2006; Hawkins and Sutton, 2011). Moreover, changes in

380 atmospheric circulation may induce substantial variations in precipitation change

381 on local scales, but this variability is smoothed out when averaging the projections

382 of different models (Knutti, Furrer, Tebaldi, Cermak \& Meehl, 2010). Thus, much

383 larger local increses or decreases in precipitation might occur than is suggested by

384 Fig. 4 (see Fig. 11.5 in Christensen et al., 2015).

386 Following the increase in saturation humidity with temperature, warming is

387 generally accompanied by an increase in atmospheric water vapor (Held and 388 Soden, 2006). Therefore, heavy short-term precipitation is likely to increase even 389 in many regions where the mean precipitation decreases. For the Baltic Sea 390 region, most RCMs suggests an increase in extreme daily precipitation both in 391 winter and in summer (Nikulin et al., 2011; Christensen et al., 2015, Fig. 11.6).

392 This also holds for the southern parts of the basin, where the same models 393 generally project a decrease in mean summer precipitation. On the other hand, 394 model simulations suggest a decrease in the number of precipitation days in the 395 southern and central parts of the Baltic Sea basin in summer (Lehtonen, 396 Ruosteenoja \& Jylhä, 2014). This might increase the risk of long dry periods, 397 particularly in the southern parts of the region (Orlowsky and Seneviratne, 2012).

\section{Wind}

399 Future changes in wind speeds are more uncertain than the changes in temperature 400 and precipitation. This holds for both the long-term mean and extremes of wind 401 speed. The 13 RCMs used in the BACC II assessment show no clear preference 402 for either increasing or decreasing wind speeds over land areas of the Baltic Sea 403 basin during this century, although local increases and decreases of $\pm 5-10 \%$ (or 
404 even more for extremes of wind speed) occur in some of the individual models

405 (Christensen et al., 2015, Figs. 11.8-11.9). Ruosteenoja, Jylhä and Kämäräinen

406 (2016) analysed the changes in mean wind speed in Finland in a large number of

407 GCMs, obtaining largely similar results.

409 Changes in wind speed are highly dependent on changes in the large-scale 410 atmospheric circulation. The upper row in Fig. 5 shows an example of an RCM 411 simulation with a very strong circulation change. A pronounced decrease in sea

412 level pressure over the Arctic Ocean combined with an increase over central

413 Europe indicates both an increase in the climatological north-south pressure

414 gradient and a northward shift of cyclone activity. Both of these factors enhance

415 wind speeds in northern Europe. By contrast, the simulation in the bottom row 416 suggests only very small changes in the pressure distribution and wind speeds.

417 Future changes in the atmospheric circulation depend on a multitude of partly 418 compensating factors and are therefore difficult to predict (Shepherd, 2014).

420 In contrast with land areas, most RCM simulations suggest a slight increase in 421 mean wind speed over the Baltic Sea (Christensen et al., 2015, Fig. 11.8; see also 422 Fig. 5). This is associated with reduced winter sea ice, which favors stronger near423 surface wind speeds by weakening the stability of the atmospheric boundary layer. 424 In many RCMs, a local maximum in wind speed change also occurs over the 425 Baltic Sea in summer, due to a strong projected warming of the Baltic Sea surface. 426 However, such stability effects are most important when the winds are relatively 427 weak. The projected changes in the strongest winds do not differ much between 428 the Baltic Sea and the surrounding land areas (Christensen et al., 2015, Fig. 11.9). 
431 Climate models project an increase in winter precipitation in the Baltic Sea basin,

432 but in a warmer climate a smaller fraction of precipitation falls as snow and

433 midwinter snowmelt episodes become more common. In general, a decrease in

434 snow cover duration and snow depth is to be expected, but the decrease will be

435 less dramatic in the colder (northern and eastern) than in the milder (southern and

436 western) parts of the region (Räisänen and Eklund, 2012; Christensen et al., 2015,

437 Fig. 11.10). This is because typical mid-winter temperatures in the coldest parts of

438 the region will remain well below zero even after a moderately large warming,

439 whereas warming in milder areas will lead to a much larger increase in the

440 frequency of above-zero winter temperatures.

442 Figure 6 illustrates this dynamics for three locations (Kiruna in Swedish Lapland,

443 Joensuu in eastern Finland, and Riga in Latvia) based on RCM simulations from

444 the ENSEMBLES project. The simulated temperatures increase at all three

445 locations and so does (in most or all models) total winter precipitation. However,

446 in Riga and Joensuu snowfall decreases throughout the winter, although less in

447 Joensuu than Riga. In Kiruna, midwinter snowfall actually increases, although the

448 snowfall in autumn and spring months is reduced. The amount of snow, as

449 indicated by the water equivalent of the snow pack, is reduced in both Riga and

450 Joensuu much more drastically than could be expected from the relatively

451 undramatic decreases in midwinter snowfall. This is partly due to a later start of

452 the snowfall season, partly because of stronger midwinter snowmelt (Räisänen

453 and Eklund, 2012). In Kiruna, the increase in midwinter snowfall nearly

454 compensates these two factors, leading to only a modest decrease in snow amount 
455 at the height of the snow season in March. Even in Kiruna, however, snow comes

456 later in the fall and melts earlier in the spring.

458 Even in the future, snow conditions will vary substantially from year to year. 459 Individual snow-rich winters are still likely to occur, although they become 460 gradually less common (Räisänen and Eklund, 2012).

462 The heaviest individual snowfall events typically occur when the temperature is 463 close or just below zero (O' Gorman, 2014). At such temperatures, the air can 464 hold more moisture than in colder conditions but is still cold enough for the 465 precipitation to fall as snow. As such temperatures are expected to remain 466 common even in the future, only small changes in daily extremes of snowfall are 467 projected for the northern and easterns parts of the Baltic Sea basin (Räisänen, 468 2015). Further southwest, where snowfall as a whole becomes substantially less 469 frequent, a slight decrease in snowfall extremes is likely, but the extremes are 470 reduced much less in percentage terms than the total winter snowfall.

\section{Hydrology}

472 Future changes in river flow are affected by changes in three main meteorological

473 factors: precipitation, evaporation, and snow conditions. The total annual runoff

474 that eventually enters the Baltic Sea is set by the difference between precipitation

475 and evapotranspiration, but the snow pack acts a major seasonal storage of water

476 that strongly regulates the seasonality of runoff generation. Snow naturally plays a

477 larger role in the colder northern than in the milder southern parts of the region 478 (Graham et al., 2008; Sonnenborg, 2015). 
480 In general, evapotranspiration is projected to increase in a warmer climate if 481 sufficient water is available, although there is substantial uncertainty in the 482 magnitude of the change (Graham et al., 2008; Collins et al., 2013, Fig. 12.25).

483 However, in the northern parts of the Baltic Sea Basin, increases in precipitation 484 are expected to overcome the increase in evaportranspiration, resulting in larger 485 total annual river discharge. Further south, the projected precipitation increase is 486 smaller and more uncertain, and most model simulations suggest reduced annual 487 mean river flow (Graham et al., 2008; Collins et al., 2013, Fig. 12.24). Although it 488 appears more likely that the increases in north will outweigh the decreases in 489 south than vice versa, the change in the total annual river flow to the Baltic Sea is 490 quite uncertain (Graham et al. 2008, Fig. 3.34).

492 The seasonal cycle of river runoff is projected to change (Graham et al., 2008; 493 Sonnenborg, 2015). In areas that are currently characterized by snowmelt floods 494 in the spring, these floods are likely to occur earlier and decrease in magnitude 495 because less snow accumulates during the shorter winter. Conversely, increases in 496 precipitation together with reduced storage in snow act to increase the mean 497 runoff and risk of flooding in winter. The runoff in late spring and summer is 498 likely to decrease in most of the basin, due to the earlier snowmelt, increased 499 evapotranspitation and possibly, particularly in the southern parts, reduced 500 summer precipitation. However, in lake-rich river basins there is a considerable 501 time lag between the runoff in the upper parts of the basin and the river flow that 502 eventually reaches the Baltic Sea (Vehviläinen and Huttunen, 1997). Changes in 503 the seasonality of runoff generation will have their strongest and most immediate 504 effects in the upper sub-basins, proceeding downward the lake chain in the course 505 of weeks and months. In regulated watersheads, the seasonality is further 
506 modulated by changes in regulation practices that may be undertaken, in part, as

507 adadption to climate change (Veijalainen, Dubrovin, Marttunen \& Vehviläinen, 508 2010).

\section{Changes in Baltic Sea ocean climate}

511 The Baltic Sea has several characteristics that make the impacts of climate change

512 potentially different, and in some respects more difficult to anticipate, than is the

513 case with the wider world ocean. First, it is a semi-enclosed basin receiving

514 abundant river runoff from the surrounding land areas. Because of this, the water

515 is far less saline than in the world ocean and the salinity is sensitive to changes in

516 both the river runoff and saltwater intrusions through the Danish Straits. Second,

517 the exchange of energy, water and momemtum between the atmosphere and the

518 Baltic Sea is modulated by seasonal ice cover, whose extent is highly sensitive to

519 winter climate. Third, ongoing land uplift counteracts the large-scale sea level rise 520 particularly in the northern parts of the Baltic Sea. Finally, the ecological impacts

521 of climate change in the Baltic Sea occur against a background of severe

522 eutrophication caused by nutrient input from the surrounding land areas.

524 In the following, five aspects of Baltic Sea ocean climate change are discussed: 525 changes in ice cover, water temperature, salinity, sea level and storm surges. Ice 526 cover and water temperature affect the climate in the land areas surrounding the 527 Baltic Sea, particularly in the relatively densely populated coastal regions. Water 528 temperature and salinity together determine the density stratification of the Baltic 529 Sea water mass, and thereby modulate the circulation of water and nutrients. 530 Salinity is also biologically important for a wide range of organisms dwelling in 
531 the Baltic Sea. Changes in mean sea level and the height of storm surges affect

532 coastal erosion and need to be considered when assessing the needs and options

533 for coastal management.

535 The Baltic Sea is affected by the atmospheric climate change that occurs over the

536 Baltic Sea itself. It is also affected by changes in river discharge from the

537 surrounding land areas and by the sea level rise in the world ocean. A range of

538 time scales are involved in the response of the Baltic Sea to climate change, with

539 water temperature and ice cover reacting much faster to atmospheric temperature

540 change than salinity responds to changes in freshwater input (Omstedt \& Hansson,

541 2006). A key tool for assessing the changes within the Baltic Sea are three-

542 dimensional regional ocean model simulations, which have been available since

543 the turn of the 21st century (Graham et al., 2008, Section 3.8; Meier, 2015).

544 Projections for the changes in ice cover and sea level have also been derived by 545 many other methods.

\section{Ice cover}

548 Ice conditions in the Baltic sea are primarily determined by the mean winter

549 temperature (Tinz, 1996; Meier, Döscher \& Halkka, 2004; Omstedt \& Hansson,

550 2006; Jylhä, Fronzek, Tuomenvirta, Carter \& Ruosteenoja, 2008; Luomaranta et

551 al. 2014). In a warmer climate, the ice cover will therefore become thinner, less

552 extensive, and less long-lived.

554 The most commonly used measure of the Baltic Sea ice winter severity is the 555 annual maximum ice extext (MIB). Several studies have derived empirical 
556 relationships between MIB and winter temperature using observations (Tinz,

557 1996; Omstedt \& Hansson, 2006; Jylhä et al. 2008; Luomaranta et al. 2014). For

558 example, Luomaranta et al. (2014) found the exponential relation

$$
M I B=A e^{-B T}
$$

560 where $T$ is the mean temperature of the November-March season averaged over

561 the Baltic Sea coast, $A=(90.2 \pm 4.2) \times 10^{3} \mathrm{~km}^{2}$ and $B=(0.253 \pm 0.015)\left({ }^{\circ} \mathrm{C}\right)^{-1}$.

562 This implies a $22 \%$ decrease in ice extent for each $1^{\circ} \mathrm{C}$ of winter warming. On the

563 other hand, totally ice-free winters are hard to reach, since some ice tends to form

564 in the north of Gulf of Bothnia and in the eastern extreme of Gulf of Finland even

565 during relatively short cold periods. Regional ocean model simulations for the

566 Baltic Sea suggest that such ice-free winters would remain very rare even under

567 the strong greenhouse gas forcing that characterises the SRES A2 scenario in the

568 late 21st century (Meier, 2006). Nevertheless, the projected warming indicates a

569 large increase in the frequency of mild ice winters already in the first half of this

570 century, together with a virtual elimination of ice winters that would have been

571 classified as severe in the 20th century (Luomaranta et al., 2014).

\section{Water temperature}

573 Following the warming of the atmosphere, the water in the Baltic Sea will become

574 warmer. However, the magnitude of this change is modulated by changes in ice

575 conditions and vertical mixing. Vertical mixing itself is affected by changes in

576 temperature and salinity, which together determine the density of sea water.

577 However, in contrast with more saline ocean water, the brackish water in the

578 Baltic Sea reaches its maximum density when the temperature is a few degrees

579 above the freezing point. These interlinked and nonlinear processes allow the 
580 warming of the surface water to differ from the warming of the air above, both in

581 its annual mean and its seasonal cycle. The vertical gradient of water temperature

582 is also projected to change, with larger warming near the surface than at greater

583 depth (Meier, 2015).

585 As a specific example, regional Baltic Sea model simulations suggest a 586 pronounced maximum of sea surface warming in the Bothnian Bay and Bothnian 587 Sea during summer (Meier et al., 2012). This results from the nonlinear 588 relationship between temperature and water density (Hordoir \& Meier, 2011).

589 After the ice melt in spring, seasonal warming first increases the density of the

590 surface water. This triggers thermal convection, which mixes the heat down in the 591 water column. Therefore, the surface water only warms up slowly. However, once 592 the temperature in the surface layer exceeds the point of maximum density, 593 further warming suppresses vertical mixing. After this, the warming at the surface 594 accelerates, because the heat input from the atmosphere is distributed in a much 595 thinner water layer. In a warmer climate, the point of maximum density is reached 596 earlier in spring. Consequently, a larger fraction of the spring- and summertime 597 heat input stays near the surface. The net result is a larger summertime 598 temperature increase in the surface water than either in the air above or in the 599 water at greater depth.

\section{Salinity}

601 Most climate change projections suggest an increase in total river runoff to the 602 Baltic Sea. The local freshwater input given by the difference of precipitation and 603 evaporation over the Baltic Sea might also increase to some extent (Rutgresson, 604 Omstedt \& Räisänen, 2002). This increased freshwater supply would reduce the 
605 salinity of the Baltic Sea water. The decrease might be substantial, although its 606 magnitude is rather uncertain. For example, in the ensemble of ocean model

607 simulations of Meier et al. (2012) the volume-averaged Baltic Sea mean salinity 608 decreases from 8 to nearly $6 \mathrm{~g} \mathrm{~kg}^{-1}$ during the $21^{\text {st }}$ century. The pattern of the 609 projected change roughly mirrors the current salinity distribution. Thus, the

610 largest decrease occurs in the Danish straits region, where the present-day salinity

611 is largest, and the smallest decrease in the eastern and northern parts of the Baltic

612 Sea, particularly the Bothnian Bay, where the water is less saline.

\section{Sea level change}

614 The sea level in the world ocean is projected to rise due to loss of land-based ice

615 masses and thermal expansion of ocean water (Church et al., 2013). On the other

616 hand, the loss of the Fennoscandian ice sheet in the end of the latest glaciation is 617 still causing ongoing land uplift due to glacial isostatic adjustment (GIA). The

618 land uplift rate varies from near zero at the Schleswig-Holstein coast in the 619 southwest to $10 \mathrm{~mm} \mathrm{yr}^{-1}$ in the Bothnian Bay (Hill, Davis, Tamisiea \& Lidberg, 620 2010; Johansson, Pellikka, Kahma \& Ruosteenoja, 2014). Therefore, the relative 621 sea level rise will be largest along the southwestern and southern coasts of the 622 Baltic Sea. Around the Gulf of Bothnia, the relative sea level is still projected to 623 decrease during this century, except for the most extreme scenarios. However, the 624 decrease will be slower than this far.

626 The rate of future global sea level rise is not well known. In the IPCC 5th 627 Assessment Report, the projections for the change from the 20-year period 19866282005 to the year 2100 range from $28-61 \mathrm{~cm}$ for the RCP2.6 scenario to $52-98 \mathrm{~cm}$ 629 for RCP8.5 (Church et al., 2013). However, some semiempirical models, built on 
630 the connection between observed sea level and temperature changes, have given

631 higher estimates of global sea level rise, in extreme cases up to $200 \mathrm{~cm}$ by the

632 year 2100 (Table 4 of Johansson et al., 2014). The largest uncertainty concerns the

633 marine-based sectors of the Antarctic ice sheet, whose response to climate change

634 is very difficult to model and might turn out to be larger than was expected in the

635 IPCC 5th Assessment. A study by DeConto \& Pollard (2016) suggests that, under 636 the high-end RCP8.5 scenario, the loss of Antarctic ice alone could raise the 637 global sea level by up to one meter by the year 2100 , and up to 15 meters by the 638 year 2500 .

640 Sea level rise will not be uniformly distributed around the world, even when local

641 land uplift or subsidence is disregarded (Church et al., 2013). The change in the

642 Baltic sea region is likely to be smaller than the global average (Johansson et al.,

643 2014; Grinsted, 2015). In particular, ice melt from the Greenland ice sheet and

644 smaller northern hemisphere high-latitude glaciers would only weakly affect the

645 sea level in the Baltic Sea. Due to changes in the Earth's gravity field and other

646 geophysical effects, the sea level rise associated with the loss of land ice is small

647 (or even locally negative) in nearby regions, but slightly larger than the global

648 average in the opposite hemisphere (Bamber \& Riva, 2010; Slangen, Katsman,

649 van de Wal, Vermeersen \& Riva, 2012).

650

651 As the best estimate, the absolute sea level rise in the Baltic Sea (before 652 accounting for land movement) would be about $80 \%$ of the global mean. Grinsted 653 (2015) combines a scenario with a mid-range $70 \mathrm{~cm}$ global sea level change 654 during this century with the simultaneous land uplift, arriving at a relative sea655 level rise of $60 \mathrm{~cm}$ near Hamburg, but a sea level fall of $35 \mathrm{~cm}$ in the Bothnian 
656 Bay. Excluded from this estimate are local effects from changes in winds and sea

657 ice. These local effects might act to increase the sea level in the northern parts of

658 the Baltic Sea, by up to $20 \mathrm{~cm}$ in the northernmost Bothnian Bay in spring (Meier,

659 2015, Fig. 13.7). However, the large uncertainty in the future rate of global sea

660 level rise also makes the estimates of local sea level change quite uncertaintain.

\section{Storm surges}

662 The impacts of sea level change depend on both the mean change and changes in

663 variability. Of particular importance are the high extremes caused by wind storms,

664 known as storm surges. Future changes in both mean and extreme wind speeds are

665 still rather uncertain, and the same applies to storm surges. Some model

666 simulations suggest an increase in extreme storm surges whereas others do not

667 (Meier, 2006). However, a recent study, in which a high-resolution hydrodynamic

668 model was driven by output from eight GCMs, supports an increase in storm

669 surges as a consensus projection for the whole Baltic Sea in all seasons

670 (Vousdoukas, Voukouvalas, Annunziato, Giardino \& Feyen, 2016). On the other

671 hand, the magnitude of the projected increase (of the order of $5 \%$, or $10 \mathrm{~cm}$ for

672 long-term extremes) is relatively modest. Therefore, the absolute change in sea

673 level extremes in the future will probably be mainly determined by the change in

674 the mean sea level, particularly in the southern Baltic Sea where the largest

675 increase in mean sea level is projected (Gräwe \& Burchard, 2012).

676

677 The distribution of storm surge heights has a heavy tail. This means that, even in 678 the absence of climate change, surges might in rare cases reach much higher than 679 even 100-year long observational records would suggest. For example, in 680 Travemünde at the German Baltic Sea coast, a surge in 1872 exceeded the normal 
681 water level by $3.2 \mathrm{~m}$ (Jensen \& Müller-Navarra, 2008). This is about $1.0 \mathrm{~m}$ higher

682 than any other surge in the time series that goes back to the 1820 s.

683

684 Environmental impacts of climate change

685 Changes in climate affect the environment in several ways. Some of the effects

686 are direct (for example, the effects of temperature and precipitation on vegetation

687 survival and productivity), others indirect (for example, changes in marine

688 ecosystems that follow when changes in nutrient input due to changed river runoff

689 alter the relative competitiveness of different species). In addition to climate

690 change, however, the environment in the Baltic Sea region is subject to nutrient

691 pollution and many other anthropogenic pressures. Moreover, some changes

692 would occur even in the absence of the human impact and climate change, for

693 example due to the continuing land uplift. Due to this complexity, it has been in

694 most cases difficult to pintpoint the climate change contribution to the

695 environmental changes observed this far (BACC II Author Team, 2015).

696 Similarly, the environmental changes that will occur in the future will result from

697 several interrelated factors of which climate change is but one.

698

699 This article gives a very brief overview of the potential environmental impacts of

700 climate change in the Baltic Sea region. The topics considered are atmospheric

701 chemistry, terrestrial and freshwater ecosystems, terrestrial carbon storage, Baltic

702 Sea biogeochemisty, ecosystems in the Baltic Sea, and finally, coastal erosion and

703 coastline changes. All of these are discussed in more depth in the first (BACC

704 Author Team, 2008) and the second (BACC II Author Team, 2015) BACC 705 assessments. 
707 Major air pollutants in the Baltic Sea region include acidifying components such

708 as sulphur and nitrogen oxides and ammonia $\left(\mathrm{NH}_{3}\right)$, together with ozone

709 (Simpson et al., 2015). Large changes in the severity of air pollution and thus its

710 impacts have taken place during the past century. The emissions increased

711 dramatically during the $20^{\text {th }}$ century and particularly after the Second World War.

712 Beginning from the 1980s, however, control measures have reduced the emissions

713 of, in particular, sulphur compounds.

715 Future changes in the level of air pollution are also expected to be primarily

716 determined by policy- and technology-driven changes in emissions. Potential

717 climate change effects are secondary, but some of them have been identified. For

718 example, climate change may slightly increase nitrogen deposition within the

719 Baltic Sea drainage basin (Langner, Andersson \& Engardt, 2009). Furthermore,

720 higher temperatures may increase ammonia emissions from land sources owing to

721 increased evaporation (Skjøth \& Geels 2013; Sutton et al., 2013). Finally, reduced

722 ice cover might lead to increased shipping and thus increased shipping emissions

723 of many pollutants over the Arctic Ocean, which would primarily affect the

724 northern parts of the Baltic Sea basin (Tuovinen, Hakola, Karlsson \& Simpson, 725 2013).

726 Terrestrial and freshwater ecosystems

727 Ecosystems both on land, in inland lakes and rivers, and in the Baltic Sea are 728 sensitive to climate (Smith et al., 2008; Dippner et al., 2008; Niemelä et al., 2015;

729 Viitasalo et al., 2015). However, they are also affected by anthropogenic pressures 730 such as loss of natural habitat, increases in carbon dioxide and ozone 
731 concentrations, toxic chemicals, and increased nutrient input via the atmosphere

732 and from agriculture and wastewater. Furthermore, the direct physical effects of

733 climate change are compounded by food web interactions and competition

734 between species. Therefore, the effects of climate change on ecosystems are in

735 many cases difficult to predict and to separate from other factors.

737 Although not the only facet of climate change, the greenhouse gas induced 738 warming of climate is the "largest" of the expected changes - that is, more clearly 739 discernible from natural variability than, for example, changes in precipitation 740 (Hawkins \& Sutton, 2011). It is therefore useful to highlight the effects of 741 temperature change with a few examples. Higher temperatures are projected to 742 lengthen the growing season for terrestrial plants, and promote northward and 743 upward shifts in the boundaries of species occurrence (Smith et al., 2008). The

744 latter will mean the advance of species in colder areas where they have not thrived 745 before, sometimes at the cost of the original species in that area, but in some cases 746 also retraction near the warm limit of the range. Examples of the potential 747 consequences are displacement of tundra plants by grasses and trees, and 748 increased share of broadleaved trees in boreal forests. Changes such as increases 749 in treeline altitude and increased plant species diversity at mountain tops are 750 already observable in nature (e.g., Kullman, 2004, 2010).

752 Continuing with forests, increased temperatures are expected to increase the 753 growth of coniferous trees in the northern parts of the Baltic Sea basin, but may 754 reduce it in the south where the growth tends to be limited by water availability 755 (Lindner et al., 2010). However, the earlier dehardening associated with milder 756 winters might make the trees more vulnerable to temperature backlashes in the 
757 spring in some areas (Jönsson, Linderson, Stjernquist, Schlyter \& Bärring, 2004).

758 Another risk associated with the warming is a northward expansion of pests and

759 pathogens (Lindner et al., 2010). Finally, the increase in temperatures may make

760 trees more prone to windthrow by delaying the freezing of the soil in the autumn

761 (Peltola, Kellomäki \& Väisänen, 1999). On the other hand, the increase in carbon

762 dioxide concentration is thought to enhance the positive and reduce the negative

763 effects of climate change on forests and plants in general (Lindner et al., 2010).

764

765 The projected atmospheric warming acts to increase the water temperature in

766 inland lakes and shorten the ice season. Due to the earlier ice break-up, the

767 seasonal warming in spring will start earlier and the stratified summer period

768 (when the warm surface water is less dense than the colder water below) will

769 become longer. The earlier ice melt will also increase the amount of sunlight

770 available for phytoplankton in early spring. The hydrological regime in lakes will

771 also change (section "Hydrology"), with potentially major changes in the

772 seasonality of water and nutrient input into lakes.

773

774 The warming of water will favor warm-water species at the expense of cold-water

775 species. Together with the increased stratification, it could also enhance

776 eutrophication. On the other hand, a shortening of the ice season reduces the rsik

777 of anoxia during winter and spring. On the whole, the effects of climate change on

778 lake ecosystems are complex and will depend on the individual characteristics of

779 lakes (Smith et al, 2008). 


\section{Terrestrial carbon storage}

782 Most studies point towards increased terrestrial carbon storage in the Baltic Sea

783 basin in the future. However, the actual outcome is uncertain due to a number of 784 compensating processes (Smith et al., 2008; Niemelä et al., 2015). Warming and 785 increased $\mathrm{CO}_{2}$ concentration both favour higher primary production, particularly 786 in the northern parts of the area where water availability is mostly not a limiting 787 factor. However, higher temperatures also increase respiration and accelerate the 788 decomposition of organic matter in the soil. Another question mark is the 789 interaction between the carbon and the nitrogen cycles (Churkina et al., 2010; de 790 Vries \& Posch, 2011). Anthropogenic nitrogen deposition has probably played a 791 major role in enhancing ecosystem carbon sequestration in Europe. Anticipated 792 decreases in nitrogen deposition due to more stringent emission control may thus 793 act to reduce the carbon sequestration in the future. Besides these factors, changes 794 in land use and forest management may also have a large impact on the ecosystem 795 carbon storage (Zaehle et al., 2007).

\section{Baltic Sea biogeochemistry}

798 The main limiting nutrients for the primary production in the Baltic Sea are 799 nitrogen and phosphorus (Smith et al., 2008). A fraction of their input to the 800 Baltic Sea occurs as deposition from the atmosphere, but over three quarters of the 801 nitrogen input and more than $90 \%$ of the phosphorus input is waterborne, entering 802 the Baltic Sea via rivers or directly from point sources at the coastline (HELCOM, 803 2015). This input of nutrients is largely dependent on human activities, 804 particularly agriculture but also forestry and releases from municipal wastewater 805 plants. After increasing dramatically for most of the $20^{\text {th }}$ century, the nutrient 
806 input has started to decrease. Nevertheless, socioeconomic factors such as

807 increasing meat consumption might make it harder to achieve further decreases in

808 the future (Hägg, Humborg, Morth, Medina \& Wulff, 2010).

809

810 Nutrient input to the Baltic Sea is also modulated by variations in meteorological

811 and hydrological conditions (HELCOM, 2011; Humborg et al., 2015). Both

812 temperature and precipitation affect the fraction of released nutrients that reaches

813 the Baltic Sea. Increases in precipitation, as projected at least for the northern

814 parts of the Baltic Sea basin, tend to increase the nutrient transport by increasing

815 river runoff. On the other hand, retention processes that remove nutrients from

816 water before it reaches the Baltic Sea may become more efficient with increasing

817 temperature (Veraart, de Klein, \& Scheffer, 2011; Hong et al., 2012). The

818 seasonality of the nutrient input is also likely to change, because the projected

819 changes in precipitation and snow conditions imply increased river runoff in

820 winter but reduced runoff during late spring and summer (Section "Hydrology").

822 The increase in nitrogen and phosphorus input has increased the biological 823 production in the Baltic Sea by a factor of 2-4 (Schneider, Eilola, Lukkari, Muller824 Karulis \& Neumann, 2015). This eutrophication has dire ecological consequencies 825 (HELCOM, 2009; Schneider et al., 2015). It promotes toxic algal blooms and the 826 development of near-dead deep-water areas due to oxygen depletion and 827 production of hydrogen sulfide $\left(\mathrm{H}_{2} \mathrm{~S}\right)$. Another potentially important 828 environmental issue in the Baltic Sea is the acidification of sea water induced by 829 increasing atmospheric $\mathrm{CO}_{2}$ concentration (Omstedt et al., 2012). 
831 How will the eutrophication-related problems and particularly the oxygen 832 depletion change in the future? If anthropogenic nutrient input is reduced 833 following the current Baltic Sea Action Plan (HELCOM, 2007), the situation is 834 projected to improve, although quite slowly. However, with constant or increasing 835 nutrient input, even larger areas with oxygen depletion would develop (Meier et 836 al., 2011; Schneider et al., 2015). This is partly due to the internal cycling of the 837 nutrients that have accumulated in the Baltic Sea and its sediments during the past 838 century, but projected climate changes also play a role. First, the solubility of 839 oxygen in the Baltic Sea water decreases with increasing temperature. Second, the 840 projected warming accelerates the recycling of organic matter in the Baltic Sea.

841 Third, increases in river runoff may increase the transport of nutrients from land 842 to the Baltic Sea. However, the net effect of runoff changes is uncertain because 843 many projections suggest a decrease in runoff from the southern parts of the

844 Baltic Sea basin (Graham et al., 2008; Collins et al., 2013, Fig. 12.24).

846 Climate change might also modify the biogeochemical conditions in the Baltic

847 Sea by altering the frequency and magnitude of saltwater inflows from the North 848 Sea. Some studies have suggested an increase in such inflows in the future, but the 849 evidence is inconclusive (Schimanke, Dieterich \& Meier, 2014; Meier, Höglund, 850 Eilola \& Almroth-Rosell, 2016). The consequences of the inflows are also 851 complicated. Contrary to intuition, stronger and more frequent saltwater inflows 852 might lead to an expansion of dead bottom areas and increased risk for toxic 853 cyanobacteria blooms, at least in some parts of the Baltic Sea (Meier et al., 2016).

855 Oceans currently absorb a quarter of the anthropogenic $\mathrm{CO}_{2}$ emissions (Ciais et 856 al., 2013, Table 6.3). The resulting acidification alters the sea water chemistry and 
857 may have serious ecological consequences. During the past 1-2 centuries, the $\mathrm{pH}$

858 of the Baltic Sea surface water is estimated to have decreased by about 0.15 . A

859 further decrease in $\mathrm{pH}$ in this century is expected. The magnitude of this decrease

860 depends primarily on the magnitude of anthropogenic $\mathrm{CO}_{2}$ emissions, with a

861 decrease of $0.4 \mathrm{pH}$ units possible under a high-end emission scenario (Omstedt et

862 al., 2012).

\section{Marine ecosystems}

865 Marine ecosystems in the Baltic Sea are strongly affected by eutrophication, toxic

866 chemicals and other anthropogenic pressures such as overfishing. However, the

867 ecosystems are also sensitive to climate. Climate change directly affects the

868 metabolism, growth, survival and productivity of individual organisms, but it also

869 indirectly influences the structure of communities, for example by shaping the

870 temporal and spatial match or mismatch of interacting species (Viitasalo et al.,

871 2015). These indirect effects are particularly difficult to predict, especially as

872 climate change is compounded by many other anthropogenic pressures.

873

874 Climate change is expected to affect the Baltic Sea ecosystems at least via

875 increases in water temperature, reduced sea ice and changes in salinity.

876 Furthermore, changes in temperature and salinity together regulate the density of

877 sea water, thus affecting its vertical mixing (Viitasalo et al., 2015). Some of the

878 effects are relatively straightforward. For example, a decrease in sea ice extent 879 and duration is a serious threat for ice-dwelling species such as the Baltic Ringed 880 Seal, which may lose much of its current winter habitat (Meier, Döscher \& 881 Halkka, 2004). Other effects are more complicated but no less important. In 
882 particular, increases in water temperature together with reduced ice cover may

883 lead to major changes in the seasonal succession and species composition of the

884 phytoplankton community (Viitasalo et al., 2015; Sommer \& Lengfellner, 2008).

885 One consequence of this is an increased risk of cyanobacteria blooms. On the

886 other hand, a decrease in salinity might reduce phytoplankton productivity, at

887 least in the Gulf of Bothnia. The decrease in salinity together with poor oxygen

888 conditions in the deep basins would also disfavor the main Baltic Sea piscivore

889 cod, with many cascading effects to lower levels in the food web (Viitasalo et al.,

890 2015).

891

892 It is still poorly known how the projected $\mathrm{CO}_{2}$-induced acidification will affect the

893 Baltic Sea ecosystems. Although many key species in the Baltic Sea food web

894 appear to be physiologically tolerant to the $\mathrm{pH}$ decreases expected in the coming

895 century, the acidification may nevertheless change the relative competitiveness of

896 different species and in this way restructure the ecosystems (Havenhand, 2012).

898 Coastal erosion and coastline changes

899 The Baltic Sea coastlines are affected by a wide range of geological processes,

900 human activities, and climatic factors. The main climatic factors are wind, waves,

901 storm surges, ice jams and flooding (Łabuz, 2015). The response of the coastline

902 to climate change depends on both the nature of the climate change and the

903 characteristics of the coastline. In general, the submergent and soft coast relief of

904 the southern Baltic Sea area is under most threat of retreat, particularly as the

905 projected sea level rise accentuates its vulnerability to storm surges and wave

906 erosion. The bedrock-dominated coasts of Finland and northern Sweden are less 
907 vulnerable, particularly as the local land uplift counteracts the absolute sea level 908 rise.

910 Apart from the effects of sea level rise, shortening of the ice season in a warmer

911 climate will also increase the exposure of shorelines to wave and wind erosion.

912 On the other hand, the erosion caused by the ice pack itself will be reduced.

913 Another potentially important but uncertain factor is changes in the frequency and

914 strength of wind storms. The direction of the wind during the storms is also

915 important, because the height of the waves and the storm surge depend on the

916 fetch of the wind over the open Baltic Sea.

\section{Conclusion}

918 The main drivers and interactions that are expected to shape climate change and

919 environmental change in the Baltic Sea region in this century are summarized in

920 Fig. 7. The ultimate drivers of climate change are divided into three categories -

921 increase in atmospheric greenhouse gases, other anthropogenic forcing and natural

922 variability. Similarly, three aspects of large-scale climate change are identified

923 that will affect the climate change in the Baltic Sea region - global warming,

924 changes in atmospheric circulation and changes in ocean circulation.

926 When considering what can and what cannot be confidently said about future

927 climate change in the Baltic Sea region, it is essential to understand that

929 1. Of the three drivers in the top row of the diagram, only the increase in 930 greenhouse gas concentrations is both reasonably well understood and predictable. Other types of anthropogenic forcing, such as changes in 
aerosol emissions or land use, may either amplify or counteract the greenhouse-gas-induced changes., but their net effect is difficult to predict. This is partly due to limitations in current scientific understanding, partly due to the short atmospheric lifetime of aerosols that allows for potentially fast changes in aerosol concentrations. Both forced (solar variability and volcanic eruptions) and unforced (internal dynamics of the climate system) natural climate variability is generally considered to have only limited predictability.

2. The best understood effect from increasing greenhouse concentrations is a thermodynamically governed widespread increase in atmospheric temperatures and moisture content, nicknamed as "global warming". Projections for changes in atmospheric and oceanic circulation are more uncertain, both because of the complicated dynamics involved and because anthropogenic circulation changes are superimposed with strong natural variability.

950 Consequently, the most certain (or least uncertain) aspects of regional climate 951 change in the Baltic Sea basin are those that are most strongly affected by the 952 large-scale global warming. These include increases in atmospheric temperature 953 and Baltic Sea water temperature, decreases in ice cover in the Baltic Sea, lakes 954 and rivers, and increasing sea level at the southern coasts of the Baltic Sea where 955 the large-scale sea level rise is not counteracted by glacial isostatic adjustment. 956 These changes can be considered nearly certain, at least after the first few decades 957 when they might still be masked by natural variability. They might only be 
958 reversed in the unexpected case that the large-scale warming would be regionally

959 cancelled by a dramatic decrease in the North Atlantic thermohaline circulation.

961 Shortening of the snow season and decrease in snow amount are both driven by

962 increased temperature but are likely to be counteracted by increased winter

963 precipitation. Consequently, changes in snow conditions are subject to somewhat

964 larger uncertainty than the warming per se. The increase in winter precipitation is

965 also at least partly driven by the large-scale warming which tends to increase the

966 atmospheric moisture content and hence enables larger moisture transport from

967 south and west. Similarly, the increase in atmospheric humidity favors stronger

968 precipitation extremes. However, precipitation is highly sensitive to atmospheric

969 circulation and its changes are therefore not as strongly governed by atmospheric

970 thermodynamics as the temperature change. It is mainly for this reason that

971 climate change projections are more uncertain for precipitation than temperature.

972 Finally, changes in wind climate are to a large extent dictated by the atmospheric

973 circulation and are therefore among the most uncertain aspects of climate change.

975 These considerations have a clear implication on the environmental impacts of

976 climate change. The impacts that are most strongly related to warming are more

977 predictable than those related to precipitation and, in particular wind changes.

978 Nevertheless, for the environmental changes climate change is only one part of

979 the story. In some cases, climate change may become a dominant driver of 980 environmental change; in others, its effects might remain small compared with the

981 direct human influence. Some drivers of climate change, such as changes in land 982 use and in $\mathrm{CO}_{2}$, ozone and aerosol concentrations, also have direct environmental 983 effects. 
985 How to reduce the uncertainty in the climate change projections for the Baltic Sea 986 region? More detailed modeling and deeper understanding of the regional 987 atmospheric, oceanic and hydrological processes will undoubtedly be helfpful. 988 However, a large part of the uncertainty originates from outside the Baltic Sea 989 region. This uncertainty can only be reduced by an improved understanding and 990 modelling of the processes that control the magnitude of the global-scale 991 warming, changes in atmospheric circulation and the North Atlantic ocean 992 circulation. A lot of hard work is still needed with all of these issues. Finally, part 993 of the uncertainty is essentially irreducible. The current understanding suggests 994 that natural climate variability is largely unpredictable in the long run, although 995 the ocean circulation might give it some predictability for the first decade or so 996 (Koenigk, König Beatty, Caian, Döscher \& Wyser, 2012). Similarly, future 997 greenhouse gas emissions will depend on political and economical decisions that 998 are extremely difficult to predict decades in advance.

\section{Further reading}

1001 BACC Author Team (2008). Assessment of Climate Change for the Baltic Sea 1002 Basin. Berlin, Heidelberg: Springer Verlag

1003 BACC II Author Team (2015). Second Assessment of Climate Change for the 1004 Baltic Sea Basin. Cham, Heidelberg, New York, Dordrecht, London: $1005 \quad$ Springer

1006 IPCC (Intergovernmental Panel on Climate Change) (2013). Climate Change 1007 2013: The Physical Science Basis. Contribution of Working Group I to the 
1008

1009

1010

\section{References}

1012 Arrhenius, S. (1896). On the influence of carbonic acid in the air upon the 1013 temperature of the ground. Philosophical Magazine and Journal of Science, $1014 \quad 41(5), 237-276$.

1015 BACC Author Team (2008). Assessment of Climate Change for the Baltic Sea 1016 Basin. Berlin, Heidelberg: Springer Verlag

BACC II Author Team (2015). Second Assessment of Climate Change for the Baltic Sea Basin. Cham, Heidelberg, New York, Dordrecht, London: Springer

Bamber, J., Riva, R. (2010). The sea level fingerprint of recent ice mass fluxes. The Cryosphere, 4, 621-627

Benestad, R. (2016). Downscaling climate information. Oxford Research Encyclopedia on Climate Science. DOI:

10.1093/acrefore/9780190228620.013.27

Bindoff, N. L., Stott, P. A., AchutaRao, K. M., Allen, M. R., Gillett, N., Gutzler, D., ... Zhang, X. (2013). Detection and Attribution of Climate Change: from Global to Regional. In IPCC, Climate Change 2013: The Physical Science Basis. Contribution of Working Group I to the Fifth Assessment Report of the Intergovernmental Panel on Climate Change (867-942). Cambridge, New York: Cambridge University Press.

Bjørge, D., Haugen, J. E. (1998). Simulation of present-day climate in HIRHAM using perfect boundaries. RegClim General Technical Report, 1, 9-16. 
1033 Carter, T. R., Posch, M., Tuomenvirta, H. (1996). The SILMU scenarios:

1034

1035

1036

1037

1038

1039

1040

1041

1042

1043

1044

1045

1046

1047

1048

1049

1050

1051

1052

1053

1054

1055

1056

1057 specifying Finland's future climate for use in impact assessment. Geophysica, 32 (1-2), 235-260.

Churkina, G., Zaehle, S., Hughes, J., Viovy, N., Chen, Y., Jung, M., ... Jones, C. (2010). Interactions between nitrogen deposition, land cover conversion, and climate change determine the contemporary carbon balance of Europe. Biogeosciences 7, 2749-2764

Christensen, J. H., Carter, T. R., Rummukainen, M. (2007). Evaluating the performance and utility of regional climate models: The PRUDENCE project. Climatic Change, 81, 1-6.

Christensen, O. B., Christensen, J. H., Machenhauer, B., Botzet, M. (1998). Very high-resolution regional climate simulations over Scandinavia. Present climate. Journal of Climate, 11, 3204-3229.

Christensen, O. B., Kjellström, E., Zorita, E. (2015). Projected Change Atmosphere. In BACC II Author team, Second Assessment of Climate Change for the Baltic Sea Basin (217-233). Cham, Heidelberg, New York, Dordrecht, London: Springer

Christensen, J. H., Räisänen, J., Iversen, T., Bjørge, D., Christensen, O. B., Rummukainen, M. (2001). A synthesis of regional climate change simulations - A Scandinavian perspective. Geophysical Research Letters, 28 (6), 1003-1006.

Church, J. A., Clark, P. U., Cazenave, A., Gregory, J. M., Jevrejeva, S., Levermann, A., ... Unnikrishnan, A. S. (2013). Sea Level Change. In IPCC, Climate Change 2013: The Physical Science Basis. Contribution of Working Group I to the Fifth Assessment Report of the Intergovernmental Panel on 

University Press.

1060 Ciais, P., Sabine, C., Bala, G., Bopp, L., Brovkin, V., Canadell, J., ... Thornton, P. 1061 (2013). Carbon and Other Biogeochemical Cycles. In IPCC, Climate 1062 Change 2013: The Physical Science Basis. Contribution of Working Group I 1063 to the Fifth Assessment Report of the Intergovernmental Panel on 1064 Climate Change (465-570). Cambridge, New York: Cambridge University $1065 \quad$ Press.

1066 Collins, M., Knutti, R., Arblaster, J., Dufresne, J.-L., Fichefet, T., Friedlingstein, 1067 P., ... Wehner, M. (2013). Long-term Climate Change: Projections, 1068 Commitments and Irreversibility. In IPCC, Climate Change 2013: The 1069 Physical Science Basis. Contribution of Working Group I to the Fifth 1070 Assessment Report of the Intergovernmental Panel on Climate Change (1029-1136). Cambridge, New York: Cambridge University Press.

1072 DeConto, R. M., Pollard, D. (2016). Contribution of Antarctica to past and future 1073 sea-level rise. Nature, 531 (7596), 591-597.

1074 Déqué, M., Somot, S., Sanchez-Gomez, E., Goodess, C. M., Jacob, D., Lenderink, 1075 G., Christensen, O. B. (2012). The spread amongst ENSEMBLES regional 1076 scenarios: regional climate models, driving general circulation models and 1077 interannual variability. Climate Dynamics, 38 (5), 951-964.

1078 Deser, C., Phillips, A., Bourdette, V., Teng, H. (2012). Uncertainty in climate 1079 change projections: the role of internal variability. Climate Dynamics, 38 $1080 \quad(3), 527-546$

1081 de Vries, W., Posch, M. (2011). Modelling the impact of nitrogen deposition, 1082 climate change and nutrient limitations on tree carbon sequestration in 
1085 Dippner, J. W., Vuorinen, I., Daunys, D., Flinkman, J., Halkka, A., Köster, F. W., 1086 ... Wasmund, N. (2008). Climate-related Marine Ecosystem Change. In: 1087 BACC Author Team, Assessment of Climate Change for the Baltic Sea 1088 Basin (221-238). Berlin, Heidelberg: Springer Verlag

1089 Eriksson, C., Omstedt, A., Overland, J. E., Percival, D. B., Mofjeld, H. O. (2007). 1090 Characterizing the European sub-Arctic winter climate since 1500 using ice, 1091 temperature, and atmospheric circulation time series. Journal of Climate, 20 $1092 \quad(21), 5316-5334$.

1093 Graham, L. P., Andréasson, J., Carlsson, B. (2007). Assessing climate change 1094 impacts on hydrology from an ensemble of regional climate models, model 1095 scales and linking methods - a case study on the Lule River basin. Climatic $1096 \quad$ Change, 81(Suppl 1), 293-307.

1097 Graham, L. P., Chen, D., Christensen, O. B., Kjellström, E., Krysanova, V., 1098 Meier, H. E. M., .. Ruosteenoja, K. (2008). Projections of future 1099 anthropogenic climate change. In: BACC Author Team, Assessment of 1100 Climate Change for the Baltic Sea Basin (133-219). Berlin, Heidelberg: $1101 \quad$ Springer Verlag

1102 Gräwe, U., Burchard, H. (2012). Storm surges in the Western Baltic Sea: the 1103 present and a possible future. Climate Dynamics, 39 (1), 165-183

1104 Grinsted, A. (2015). Projected Change - Sea level. In BACC II Author team, 1105 Second Assessment of Climate Change for the Baltic Sea Basin (253-263).

1106 Cham, Heidelberg, New York, Dordrecht, London: Springer

1107 Grotch, S. L., MacCracken, M. C. (1991). The use of general circulation models 1108 to predict regional climatic change. Journal of Climate, 4 (3), 286-303. 
1109 Hägg, H. E., Humborg, C., Morth, C. M., Medina, M. R., Wulff, F. (2010).

1110 Scenario analysis on protein consumption and climate change effects on

1111 riverine N export to the Baltic Sea. Environmental Science and Technology,

$1112 \quad 44(7), 2379-2385$

1113 Hansen, J., Ruedy, R., Sato, M., Lo, K. (2010). Global surface temperature

1114 change. Reviews of Geophysics, 48 (4), RG4004,

1115 doi:10.1029/2010RG000345

1116 Havenhand, J. N. (2012). How will acidification affect Baltic Sea ecosystems? An

1117 assessment of plausible impacts on key functional groups. Ambio, 41 (6),

$1118 \quad 637-644$

1119 Hawkins, E., Sutton, R. (2009). The potential to narrow uncertainty in regional 1120 climate predictions. Bulletin of the American Meteorological Society, 90 (8), $1121 \quad 1095-1106$.

1122 Hawkins, E., Sutton, R. (2011). The potential to narrow uncertainty in projections 1123 of regional precipitation change. Climate Dynamics, 37 (1), 407-418.

1124 HELCOM (2007). HELCOM Baltic Sea Action Plan. 1125 http://helcom.fi/Documents/Baltic sea action plan/BSAP_Final.pdf

1126 HELCOM (2009). Eutrophication in the Baltic Sea - An integrated thematic 1127 assessment of the effects of nutrient enrichment in the Baltic Sea region.

1128 Baltic Sea Environment Proceedings, 115B. Helsinki, Helsinki 1129 Commission.

1130 HELCOM (2011). The Fifth Baltic Sea Pollution Load Compilation (PLC-5). 1131 Baltic Sea Environment Proceedings, 128. Helsinki, Helsinki Commission.

1132 HELCOM (2015). Updated Fifth Baltic Sea pollution load compilation (PLC-5.5). 1133 Baltic Sea Environment Proceedings, 145. Helsinki, Helsinki Commission. 
1134 Held, I. M., Soden, B. J. (2006). Robust responses of the hydrological cycle to 1135 global warming. Journal of Climate, 19 (21), 5686-5699.

1136 Hill, E. M., Davis, J. L., Tamisiea, M. E., Lidberg, M. (2010). Combination of 1137 geodetic observations and models for glacial isostatic adjustment fields in $1138 \quad$ Fennoscandia. Journal of Geophysical Research, 115 (B7), B07403

1139 Holmes, C. R., Woollings, T., Hawkins, E., de Vries, H. (2016). Robust future 1140 changes in temperature variability under greenhouse gas forcing and the 1141 relationship with thermal advection. Journal of Climate, 29 (6), 2221-2236

1142 Hong, B., Swaney, D. P., Morth, C. M., Smedberg, E., Hägg, H. E., Humborg, C., $1143 \quad$... Bouraoui, F. (2012). Evaluating regional variation of net anthropogenic 1144 nitrogen and phosphorus inputs (NANI/NAPI), major drivers, nutrient 1145 retention pattern and management implications in the multinational areas of $1146 \quad$ Baltic Sea basin. Ecological Modelling, 227, 117-135

1147 Hordoir, R., Meier, H. E. M. (2011). Effect of climate change on the thermal 1148 stratification of the Baltic Sea: a sensitivity experiment. Climate Dynamics, $1149 \quad 38(9), 1703-1713$.

1150 Humborg, C., Andersen, H. E., Blenckner, T., Gadegast, M., Giesler, R., 1151 Hartmann, J., ... Weyhenmeyer, G. (2015). Environmental Impacts 1152 Freshwater Biogeochemistry. In BACC II Author team, Second Assessment 1153 of Climate Change for the Baltic Sea Basin (307-336). Cham, Heidelberg, $1154 \quad$ New York, Dordrecht, London: Springer

1155 IPCC (Intergovernmental Panel on Climate Change) (1990). Climate Change. The 1156 IPCC Scientific Assessment. Cambridge: Cambrige University Press.

1157 IPCC (Intergovemental Panel on Climate Change) (1996). Climate Change 1995:

1158 The Science of Climate Change. Contribution of Working Group I to the 1159 Second Assessment Report of the Intergovernmental Panel on Climate 

Press.

1162 IPCC (Intergovemental Panel on Climate Change) (2001). Climate Change 2001:

1163 The Scientific Basis. Contribution of Working Group I to the Third 1164 Assessment Report of the Intergovernmental Panel on Climate Change: 1165 Summary for Policymakers. Cambridge: Cambrige University Press.

1166 IPCC (Intergovernmental Panel on Climate Change) (2013). Climate Change 1167 2013: The Physical Science Basis. Contribution of Working Group I to the 1168 Fifth Assessment Report of the Intergovernmental Panel on Climate 1169 Change. Cambridge, New York: Cambridge University Press.

1170 Jacob, D., Petersen, J., Eggert, N., Alias, A., Christensen, O. B., Bouwer, L. M., 1171 ... Yiou, P. (2014). EURO-CORDEX: new high-resolution climate change 1172 projections for European impact research. Regional Environmental Change, $1173 \quad 14(2), 563-578$.

1174 Jacob, D., Podzun, R. (1997). Sensitivity studies with the regional climate model 1175 REMO. Meteorology and Atmospheric Physics, 63 (1), 119-129

1176 Jensen, J., Müller-Navarra, S. H. (2008). Storm surges on the German coast. Die $1177 \quad$ Küste, 74 ICCE, 92-124.

1178 Johansson, M. M., Pellikka, H., Kahma, K. K., Ruosteenoja, K. (2014). Global sea 1179 level rise scenarios adapted to the Finnish coast. Journal of Marine Systems, $1180 \quad 129(1), 35-46$

1181 Jóhannesson, T., Jónsson T., Källén, E., Kaas, E. (1995). Climate change 1182 scenarios for the Nordic countries. Climate Research, 5 (3), 181-195

1183 Jönsson, A. M., Linderson, M.-L., Stjernquist, I, Schlyter P., Bärring, L. (2004). 1184 Climate change and the effect of temperature backlashes causing frost 1185 damage in Picea abies. Global and planetary change, 44 (1-4), 195-207. 
1186 Jylhä, K., Fronzek, S., Tuomenvirta, H., Carter, T. R., Ruosteenoja, K. (2008).

1187 Changes in frost, snow and Baltic Sea ice by the end of the twenty-first

1188 century based on climate model projections for Europe. Climatic Change,

$1189 \quad 86(3), 441-462$

1190 Kämäri, J. (1997). Preface. Boreal Enviroment Research, 2 (1), 1.

1191 Kjellström, E., Bärring, L., Jacob, D., Jones, R., Lenderink, G., Schär, C. (2007).

1192 Modelling daily temperature extremes: Recent climate and future changes

$1193 \quad$ over Europe. Climatic Change 81 (S1), 249-265.

1194 Knutti, R., Furrer, R., Tebaldi, C., Cermak, J., Meehl, G. A. (2010). Challenges in

1195 Combining Projections from Multiple Climate Models. Journal of Climate,

$1196 \quad 23(10), 2739-2758$.

1197 Koenigk, T., König Beatty, C., Caian, M., Döscher, R., Wyser, K. (2012).

1198 Potential decadal predictability and its sensitivity to sea ice albedo

1199 parameterization in a global coupled model. Climare Dynamics 38 (11), $1200 \quad 2389-2408$.

1201 Kullman, L. (2004). Long-term geobotanical observations of climate change 1202 impacts in the Scandes of West-Central Sweden. Nordic Journal of Botany, $24(4), 445-467$.

1204 Kullman, L. (2010). Alpine flora dynamics - a critical review of responses to 1205 climate change in the Swedish Scandes since the early 1950s. Nordic $1206 \quad$ Journal of Botany, 28 (4), 398-408.

1207 Łabuz, T. A.., (2015). Environmental Impacts - Coastal Erosion and Coastline 1208 Changes. In BACC II Author team, Second Assessment of Climate Change 1209 for the Baltic Sea Basin (381-396). Cham, Heidelberg, New York, 1210 Dordrecht, London: Springer 
1211 Langner, J., Andersson, C., Engardt, M. (2009). Atmospheric input of nitrogen to 1212 the Baltic Sea basin: present situation, variability due to meteorology and 1213 impact of climate change. Boreal Environment Research,14 (1), 226-237

1214 Lehtonen, I., Ruosteenoja, K., Jylhä, K. (2014). Projected changes in European 1215 extreme precipitation indices on the basis of global and regional climate 1216 model ensembles. International Journal of Climatology, 34 (4), 1208-1222.

1217 Lindner, M., Maroschek, M., Netherer, S., Kremer, A., Barbati, A., Garcia1218 Gonzalo, J., ... Marchetti, M. (2010). Climate change impacts, adaptive 1219 capacity, and vulnerability of European forest ecosystems. Forest Ecology $1220 \quad$ and Management, 259 (4), 698-709

1221 Luomaranta, A., Ruosteenoja, K., Jylhä, K., Gregow, H., Haapala, J., Laaksonen, 1222

1224 Maraun, D. (2013). When will trends in European mean and heavy daily $1225 \quad$ precipitation emerge? Environmental Research Letters, 8 (1), 014004.

1226 Meier, H. E. M. (2006). Baltic Sea climate in the late twenty-first century: a 1227 dynamical downscaling approach using two global models and two emission 1228 scenarios. Climate Dynamics, 27 (1), 39-68.

Meier, H. E. M. (2015). Projected Change - Marine Physics. In BACC II Author team, Second Assessment of Climate Change for the Baltic Sea Basin (243251). Cham, Heidelberg, New York, Dordrecht, London: Springer

Meier, H. E. M., Döscher, R., Halkka, A. (2004). Simulated distributions of Baltic sea-ice in waming climate and consequences for the winter habitat of the Baltic ringed seal. Ambio, 33 (4), 249-256.

1235 Meier, H. E. M., Andersson, H. C., Eilola, K., Gustafsson, B., Kuznetsov I., 1236 Müller-Karulis, B., ... T., Savchuk, O. P. (2011). Hypoxia in future climates 
- a model ensemble study for the Baltic Sea. Geophysical Research Letters,

1239 Meier, H. E. M., Hordoir, R., Andersson, H. C., Dieterich, C., Eilola, K., 1240 Gustafsson, B. G., ... Schimanke, S. (2012). Modeling the combined impact 1241 of changing climate and changing nutrient loads on the Baltic Sea 1242 environment in an ensemble of transient simulations for 1961-2099. $1243 \quad$ Climate Dynamics, 39 (9), 2421-2441.

1244 Meier, H. E. M., Höglund, A., Eilola, K., Almroth-Rosell, E. (2016). Impact of 1245 accelerated future global mean sea level rise on hypoxia in the Baltic Sea. 1246 Climate Dynamics, doi: 10.1007/s00382-016-3333-y

1247 Mitchell, J. F. B., Manabe, S., Meleshko, V., Tokioka, T. (1990). Equilibrium 1248 Climate Change - and its Implications for the Future. In: IPCC, Climate 1249 Change. The IPCC Scientific Assessment (131-172). Cambridge: Cambrige $1250 \quad$ University Press.

1251 Morice, C. P., Kennedy, J. J., Rayner, N. A., Jones, P. D. (2012). Quantifying 1252 uncertainties in global and regional temperature change using an ensemble 1253 of observational estimates: The HadCRUT4 dataset. Journal of Geophysical 1254

1255 Nakićenović, N., Swart R. (Eds.) (2000). Emissions Scenarios. A special report of 1256 Working Group III of the Intergovernmental Panel on Climate Change. 1257 Cambridge: Cambridge University Press.

1258 Niemelä, P., Tolvanen, H., Rönkä, M., Kellomäki, S., Krug, J., Schurgers, G., ... 1259 Kalliola, R. (2015). Environmental Impacts - Coastal Ecosystems, Birds 1260 and Forests. In BACC II Author team, Second Assessment of Climate 1261 Change for the Baltic Sea Basin (291-306). Cham, Heidelberg, New York, 1262 Dordrecht, London: Springer 
1263 Nikulin, G., Kjellström, E., Hansson, U., Jones, C., Strandberg, G., Ullerstig, A. 1264 (2011). Evaluation and future projections of temperature, precipitation and 1265 wind extremes over Europe in an ensemble of regional climate simulations. $1266 \quad$ Tellus, 63A (1), 41-55

1267 O' Gorman, P (2014). Contrasting responses of mean and extreme snowfall to $1268 \quad$ climate change. Nature, 512 (7515), 416-418

1269 Omstedt, A., Hansson, D. (2006). The Baltic Sea ocean climate system memory 1270 and response to changes in the water and heat balance components. $1271 \quad$ Continental Shelf Research, 26 (2), 236-251.

1272 Omstedt, A., Edman, M., Claremar, B., Frodin, P., Gustafsson, E., Humborg, C., ... 1273 Yurova, A. (2012). Future changes of the Baltic Sea acid-base (pH) and $1274 \quad$ oxygen balances. Tellus, 64B, 19586

1275 Orlowsky, B., Seneviratne, S. I. (2012). Global changes in extreme events: 1276 regional and seasonal dimension. Climatic Change, 116 (3), 669-696.

1277 Peltola, H., Kellomäki, S., Väisänen, H. (1999). Model computations of the 1278 impact of climatic change on the windthrow risk of trees. Climatic Change, $1279 \quad 41(1), 17-36$

1280 Pryor, S. C., Barthelmie, R. J. (2010). Climate change impacts on wind energy: a 1281 review. Renewable and Sustainable Energy Reviews, 14 (1), 430-437

1282 Räisänen, J. (1994). A comparison of the results of seven GCM experiments in 1283 northern Europe. Geophysica, 30 (1-2), 3-30

1284 Räisänen, J. (2002). $\mathrm{CO}_{2}$-induced changes in interannual temperature and 1285 precipitation variability in 19 CMIP2 experiments. Journal of Climate, 15 $1286 \quad$ (9), 2395-2411. 
1287 Räisänen, J. (2015). Twenty-first century changes in snowfall climate in Northern 1288 Europe in ENSEMBLES regional climate models. Climate Dynamics, 46 $1289 \quad(1), 339-353$

1290 Räisänen, J., Eklund, J. (2012). 21st Century changes in snow climate in Northern 1291 Europe: a high-resolution view from ENSEMBLES regional climate 1292 models. Clim Dyn 38: 2575-2591

1293 Räisänen, J., Ruokolainen, L. (2006). Probabilistic forecasts of near-term climate 1294

1303 Räisänen, J., Hansson, U., Ullerstig, A., Döscher, R., Graham, L. P., Jones, C., ... 1304 Willén, U. (2004). European climate in the late 21st century: regional 1305 simulations with two driving global models and two forcing scenarios. 1306 Climate Dynamics, 22 (1), 13-31.

1307 Rummukainen, M., Räisänen, J., Bringfelt, B., Ullerstig, A., Omstedt, A., Willén, 1308 U., ... Jones, C. (2000). A regional climate model for northern Europe 1309 model description and results from the downscaling of two GCM control $1310 \quad$ simulations. Climate Dynamics, 17 (5), 339-359. 
1311 Ruosteenoja, K., Jylhä, K., Kämäräinen, M. (2016). Climate projections for 1312 Finland under the RCP forcing scenarios. Geophysica, 51 (1), 17-50.

1313 Rutgersson, A., Omstedt, A., Räisänen, J. (2002). Net precipitation over the Baltic 1314 Sea during present and future climate conditions. Climate Research, 22 (1), $1315 \quad 27-39$.

1316 Sælthun, N. R. (1992). Klimaendringer og energiproduksjon: en orientering. 1317 Vannet i Norden (Newsletter of the Nordic Association for Hydrology), 25 $1318 \quad$ (2): 8-12.

1319 Sælthun, N. R., Aittoniemi, P., Bergström, S., Einarsson, K., Jóhannesson, T., 1320 Lindström, G., Ohlsson, P. E., Thomsen, T., Vehviläinen, B., Aamodt, K. O. 1321 (1998). Climate Change Impacts on Runoff and Hydropower in the Nordic 1322 Countries. TemaNord 1998:522. Copenhagen, Nordic Council of Ministers. 1323 Schimanke, S., Dieterich, C., Meier, H. E. M. (2014). An algorithm based on sea1324 level pressure fluctuations to identify major Baltic inflow events. Tellus, $1325 \quad 66 \mathrm{~A}, 23452$

1326 Schneider, B., Eilola, K., Lukkari, K., Muller-Karulis, B., Neumann, T. (2015). 1327 Environmental Impacts - Marine Biogeochemistry. In BACC II Author 1328 team, Second Assessment of Climate Change for the Baltic Sea Basin (3371329 361). Cham, Heidelberg, New York, Dordrecht, London: Springer

1330 Shepherd, T. G. (2014). Atmospheric circulation as a source of uncertainty in $1331 \quad$ climate change projections. Nature Geoscience, 7 (10), 703-708.

1332 Simpson, D., Bartnicki, J., Jalkanen, J.-P., Hansson, H.-C., Hertel, O., Langner, J., 1333 Pryor, S. C. (2015). Environmental Impats - Atmospheric chemistry. In 1334 BACC II Author team, Second Assessment of Climate Change for the Baltic 1335 Sea Basin (267-289). Cham, Heidelberg, New York, Dordrecht, London: $1336 \quad$ Springer 
1337 Skjøth, C. A., Geels, C. (2013). The effect of climate and climate change on 1338 ammonia emissions in Europe. Atmospheric Chemistry and Physics, 13 (1), $1339 \quad 117-128$

1340 Slangen, A. B. A., Katsman, C., van de Wal, R. S. W., Vermeersen, L. L. A., Riva 1341 R. E. M. (2012). Towards regional projections of twenty-first century sea1342 level change based on IPCC SRES scenarios. Climate Dynamics, 38 (5), 1343 $1191-1209$

1344 Smith, B., Aasa, A., Ahas, R., Blenckner, T., Callaghan, T. V., de Chazal, J., ... 1345 Wolf, A. (2008). Climate-related Change in Terrestrial and Freshwater 1346 Ecosystems. In: BACC Author Team, Assessment of Climate Change for the 1347 Baltic Sea Basin (221-238). Berlin, Heidelberg: Springer Verlag

1348 Smith, T. M., Reynolds, R. W., Peterson, T. C., Lawrimore, J. (2008). 1349 Improvements to NOAA's historical merged land-ocean surface 1350 temperature analysis (1880-2006). Journal of Climate, 21 (10), 2283-2296.

1351 Sommer, U., Lengfellner, K. (2008). Climate change and the timing, magnitude, 1352 and composition of the phytoplankton spring bloom. Global Change 1353 Biology, $14(6), 1199-1208$

1354 Sonnenborg, T. O. (2015). Projected Change - Hydrology. In BACC II Author 1355 team, Second Assessment of Climate Change for the Baltic Sea Basin (2351356 242). Cham, Heidelberg, New York, Dordrecht, London: Springer

1357 Stouffer, R. J., Manabe, S., Bryan, K. (1989). Interhemispheric asymmetry in 1358 climate response to a gradual increase of atmospheric $\mathrm{CO}_{2}$. Nature, 342, $1359 \quad 660-662$

1360 Sutton, M. A., Reis, S., Riddick, S. N., Dragosits, U., Nemitz, E., Theobald, M. 1361 R., ... Vries, W. D. (2013). Towards a climate-dependent paradigm of 
ammonia emission and deposition. Philosophical Transactions of the Royal Society B: Biological Sciences, 368(1621), 20130166.

1364 Taylor, K. E., Stouffer R. J, Meehl, G. A. (2012). An overview of CMIP5 and the experiment design. Bulletin of the American Meteorological Society, 93 (4),

1367 Tinz, B. (1996). On the relation between annual maximum extent of ice cover in 1368 the Baltic Sea level pressure as well as air temperature field. Geophysica, 32 risks to Northern European forests in a changing climate. In: Matyssek, R., Clarke, N., Cudlin, P., Mikkelsen, T. N., Tuovinen, J. P., Wieser, G., Paoletti, E. Climate Change, Air Pollution and Global Challenges Understanding and Perspectives from Forest Research (77-99). Amsterdam: Elsevier.

van der Linden, P., Mitchell, J. F. B. (2009). ENSEMBLES: Climate Change and its Impacts: Summary of research and results from the ENSEMBLES project. Met Office Hadley Centre, FitzRoy Road, Exeter EX1 3PB, UK.

Available at: $\quad$ http://ensembles-
eu.metoffice.com/docs/Ensembles_final_report_Nov09.pdf

van Vuuren, D. P., Edmons, J., Kainuma, M., Riahi, K., Thomson, A., Hibbard, K., ... Rose, S. K. (2011). The representative concentration pathways: an overview. Climatic Change, 109 (1-2), 5-31

1385 Finland. Boreal Environment Research 2 (1), 3-18 
1386 Veijalainen, N., Dubrovin, T., Marttunen, M., Vehviläinen, B. (2010). Climate 1387 change impacts on water resources and lake regulation in the Vuoksi $1388 \quad$ watershead in Finland. Water Resources Management, 24 (13), 3437-3459.

1389 Veraart, A. J., de Klein, J. J. M., Scheffer, M. (2011). Warming can boost 1390 denitrification disproportionately due to altered oxygen dynamics. PLoS 1391 ONE 6 (3), e18508. doi:10.1371/journal.pone.0018508

1392 Viitasalo, M., Blenckner, T., Gårdmark, A., Kaartokallio, H., Kautsky, L., Kuosa, 1393 H., ... Wikner, J. (2015). Environmental Impacts - Marine Ecosystems. In 1394 BACC II Author team, Second Assessment of Climate Change for the Baltic 1395 Sea Basin (363-380). Cham, Heidelberg, New York, Dordrecht, London: $1396 \quad$ Springer

1397 Vousdoukas, M.I., Voukouvalas, E., Annunziato, A., Giardino, A., Feyen, L. 1398 (2016). Projections of extreme storm surge levels along Europe. Climate 1399 Dynamics, doi: 10.1007/s00382-016-3019-5.

1400 Watson, R. T., Rodhe, H., Oeschger H., Siegenthaler, U. (1990). Greenhouse 1401 Gases and Aerosols. In: IPCC, Climate Change. The IPCC Scientific 1402 Assessment (1-40). Cambridge: Cambrige University Press.

1403 Wibig, J., Maraun, D., Benestad, R., Kjellström, E., Lorenz, P., Christensen, O. B. 1404 (2015). Projected Change - Models and Methodology. In BACC II Author 1405 team, Second Assessment of Climate Change for the Baltic Sea Basin (1891406 215). Cham, Heidelberg, New York, Dordrecht, London: Springer

1407 Ylhäisi, J. S., Räisänen, J. (2014). Twenty-first century changes in daily 1408 temperature variability in CMIP3 climate models. International Journal of $1409 \quad$ Climatology, 34 (5), 1414-1428. 
1410 Zaehle, S., Bondeau, A., Carter, T. R., Cramer, W., Erhard, M., Prentice, I. C., ... 1411 Sykes, M. (2007). Projected changes in terrestrial carbon storage in Europe 1412 under climate and land-use change, 1990-2100. Ecosystems 10 (3), 380-401 1413

1414 


\section{Figures}
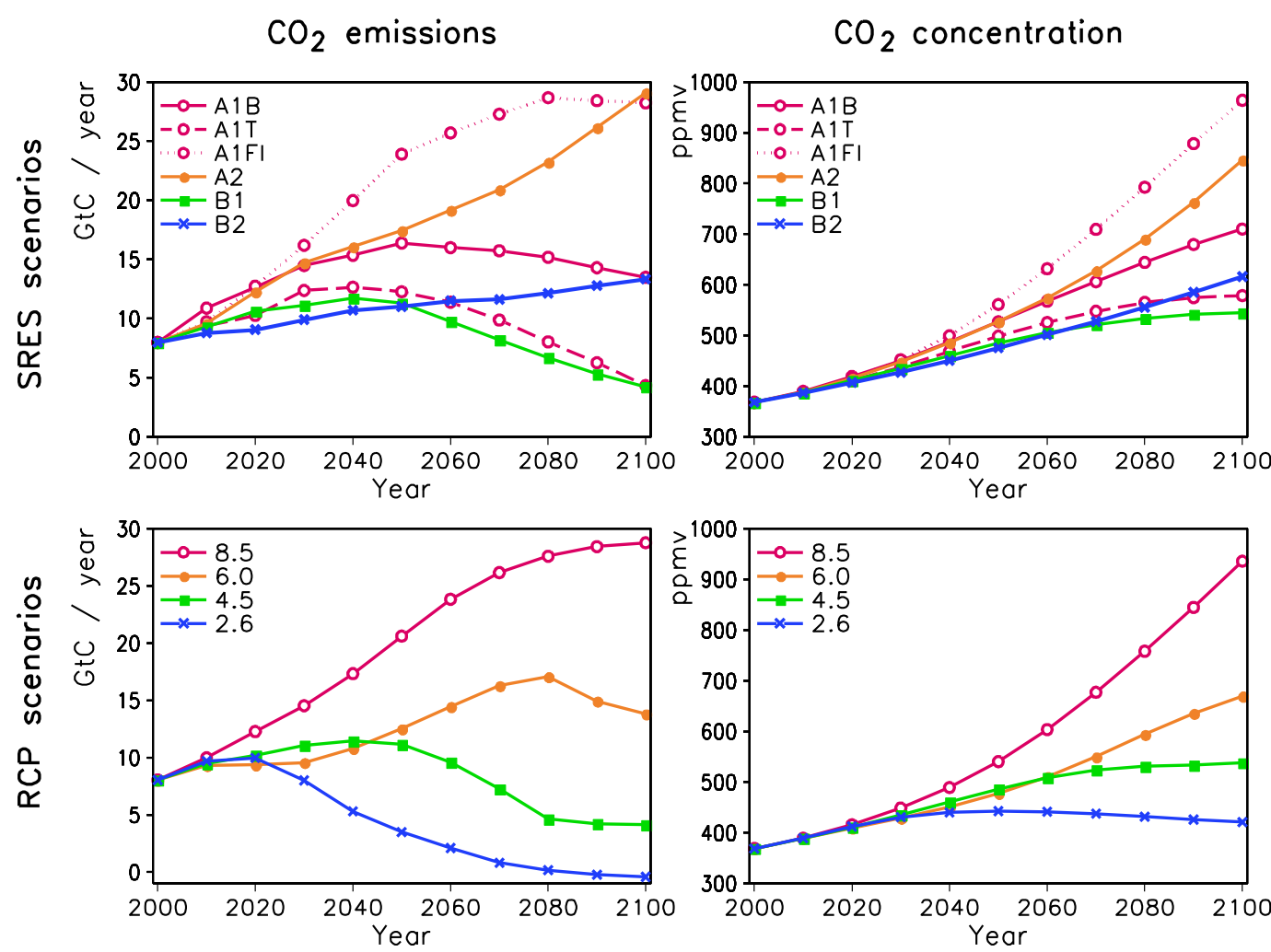

1416

1417 Figure 1. Total anthropogenic $\mathrm{CO}_{2}$ emissions (left) and $\mathrm{CO}_{2}$ concentrations for the SRES

1418 (top) and RCP (bottom) scenarios. The figure is based on the best-estimate values given

1419 in Appendix II of IPCC (2001) and Appendix II of IPCC (2013).

1420 


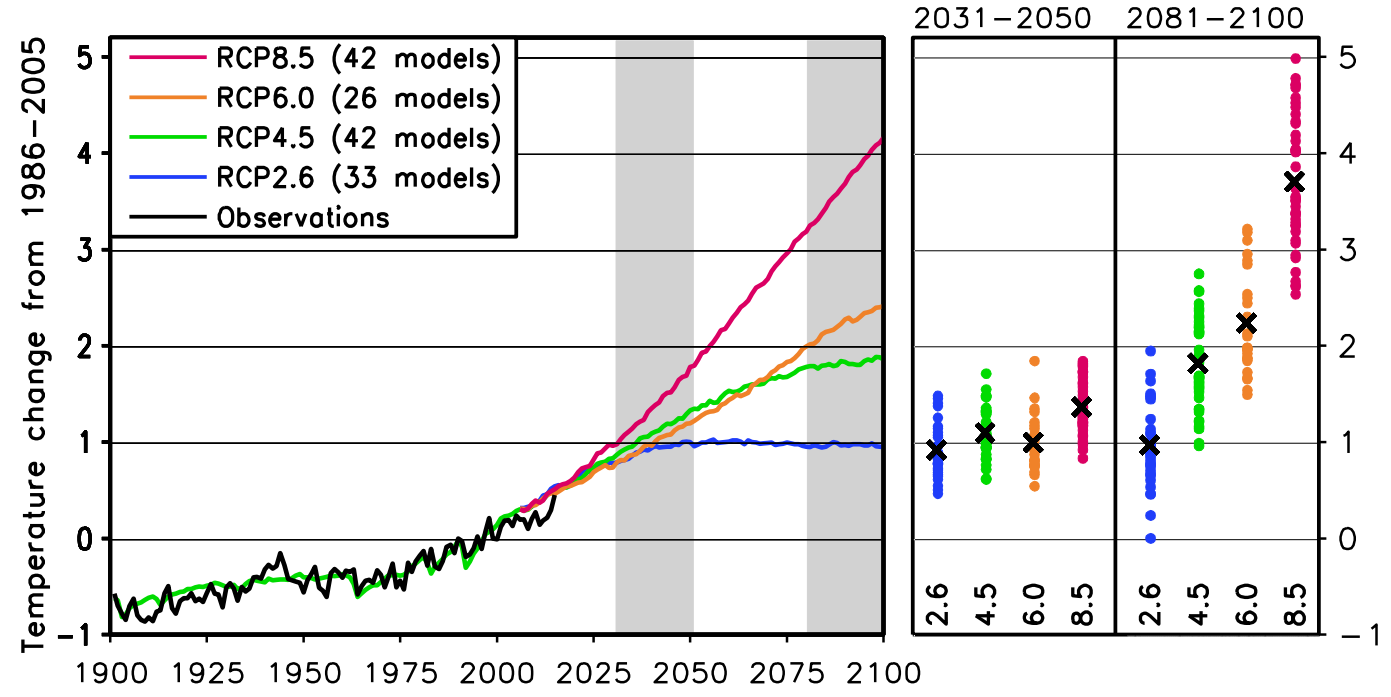

1423 Figure 2. Global mean temperature change under the four RCP scenarios, as simulated

1424 by the models used by Collins et al. (2013). Left: multi-model mean change relative to the 1425 mean temperature in 1986-2005. The observed temperature time series up to the year 14262015 is given as the mean of the HadCRUT4 (Morice, Kennedy, Rayner \& Jones, 2012),

1427 GISS (Hansen, Ruedy, Sato \& Lo, 2010) and NCDC (Smith, Reynolds, Peterson \& 1428 Lawrimore, 2008) estimates. Right: Temperature changes in the individual models from 1429 1986-2005 to 2031-2050 and 2081-2100. Unit is ${ }^{\circ} \mathrm{C}$. 


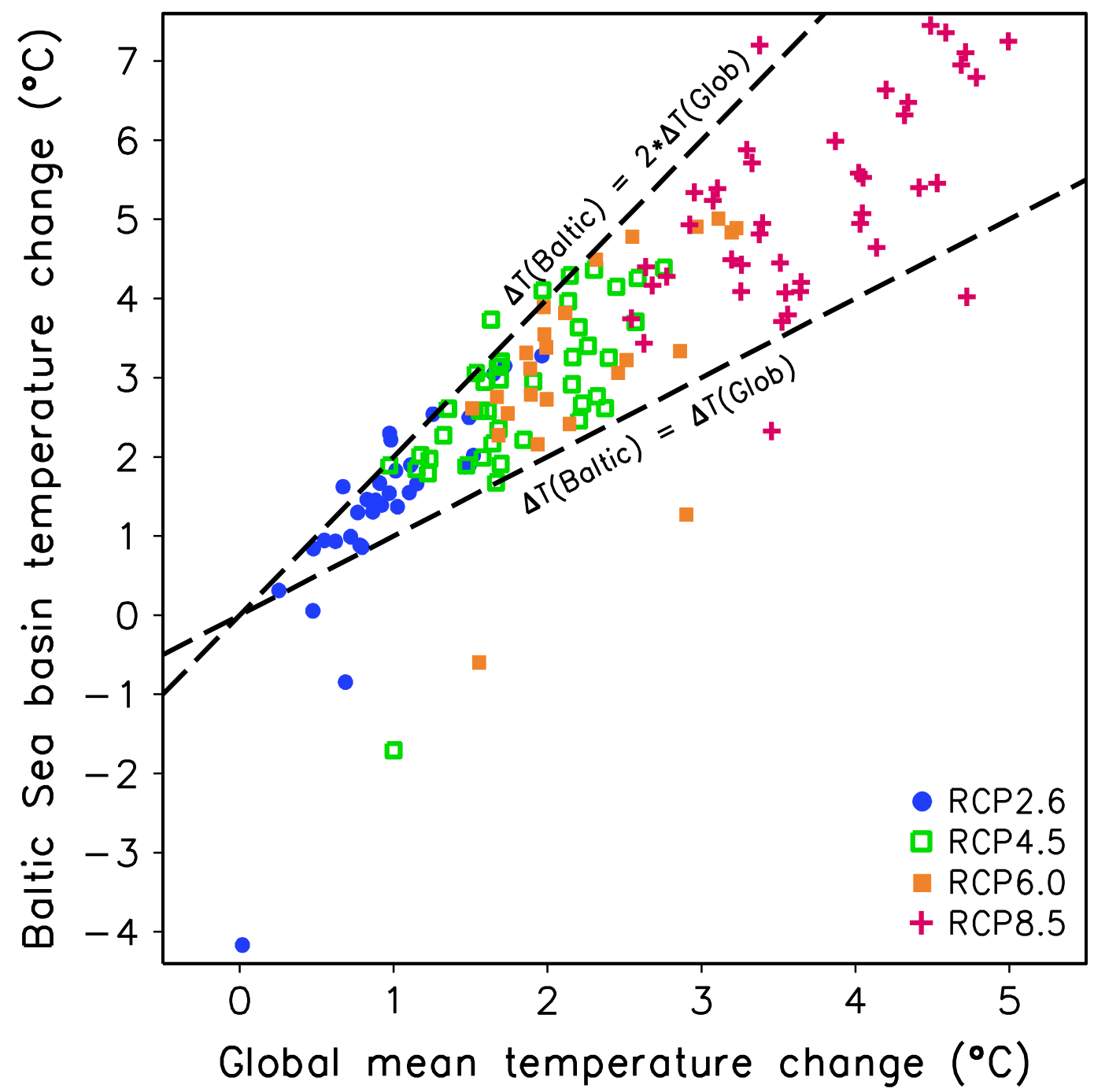

1432 Figure 3. Comparison between global (horizontal axis) and Baltic Sea drainage basin

1433 (vertical axis) area and annual mean temperature changes from 1986-2005 to 2081-

1434 2100. The same GCM simulations are included as in Fig. 2 (33 for RCP2.6, 42 for

$1435 R C P 4.5,26$ for RCP6.0 and 42 for RCP8.5).

1436 
a) $\Delta T(D e c-J a n-F e b)$

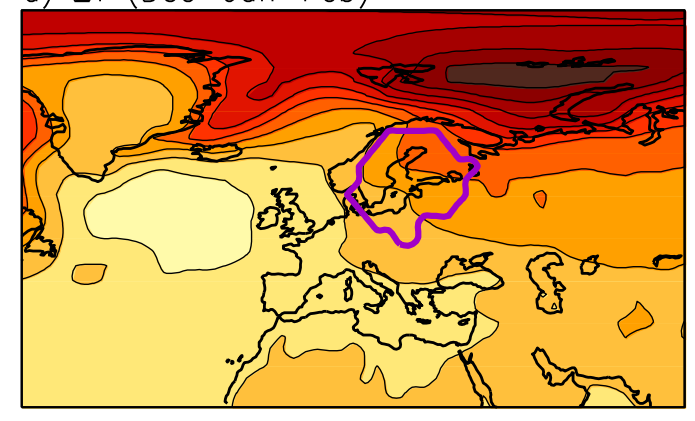

$\begin{array}{lllllllllll}1 & 2 & 3 & 4 & 5 & 6 & 7 & 8 & 9 & 10^{\circ} \mathrm{C}\end{array}$

c) $\Delta T$ (Jun-Jul-Aug)

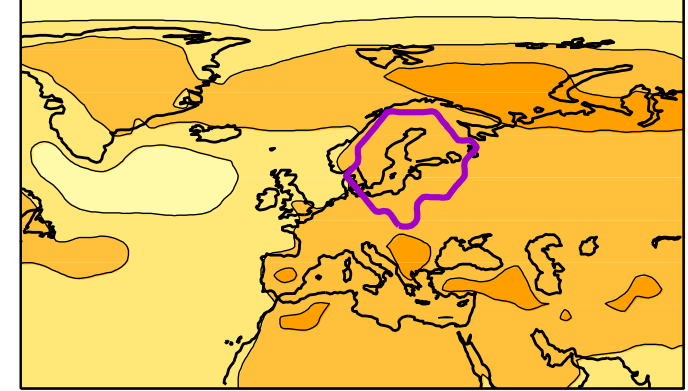

$\begin{array}{llllllllll}1 & 2 & 3 & 4 & 5 & 6 & 7 & 8 & 9 & 10^{\circ} \mathrm{C}\end{array}$

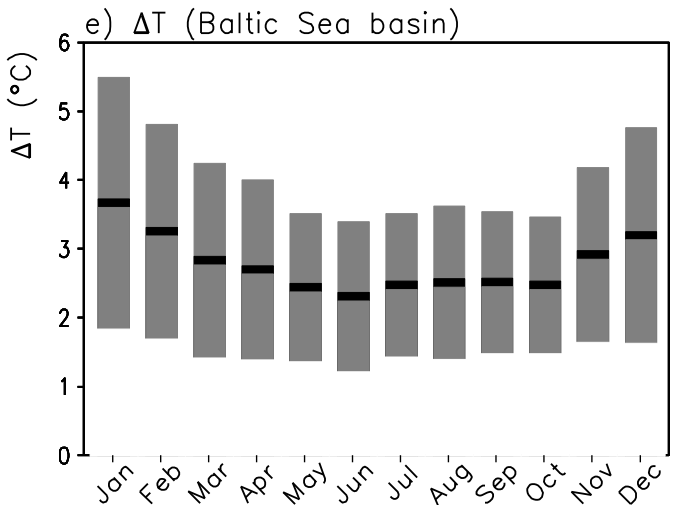

b) $\Delta P($ Dec-Jan-Feb)

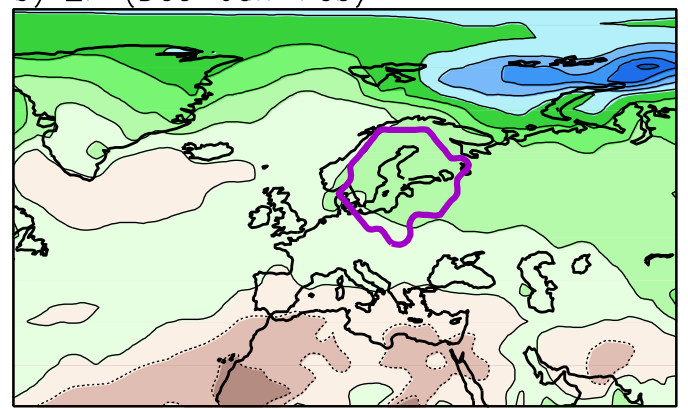

$-20-1001020304050607080 \%$

d) $\Delta P($ Jun-Jul-Aug)
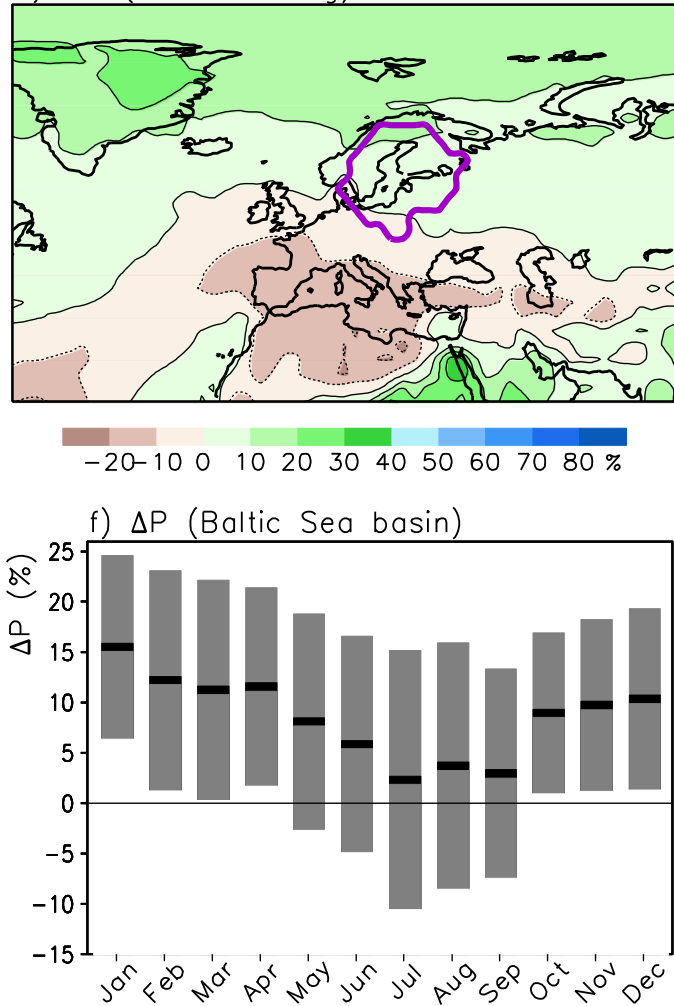

1438 Figure 4. Temperature change ( $\Delta T)$ and precipitation change $(\Delta P)$ from 1986-2005 to

1439 2081-2100 under the RCP4.5 scenario in the 42 GCMs used by Collins et al. (2013). (a)-

1440 (d): maps of multi-model mean change. (e)-(f) Seasonal cycles of Baltic Sea drainage

1441 basin mean temperature change and precipitation change. The black lines show the

1442 multi-model mean and the grey bars the mean \pm 1 standard deviation (thus, this range

1443 covers approximately two thirds of the model projections). The Baltic Sea drainage basin

1444 is delineated by the thick purple line in $(a)-(d)$. For reference, the multi-model global

1445 mean warming for these simulations is $1.8^{\circ} \mathrm{C}$. 

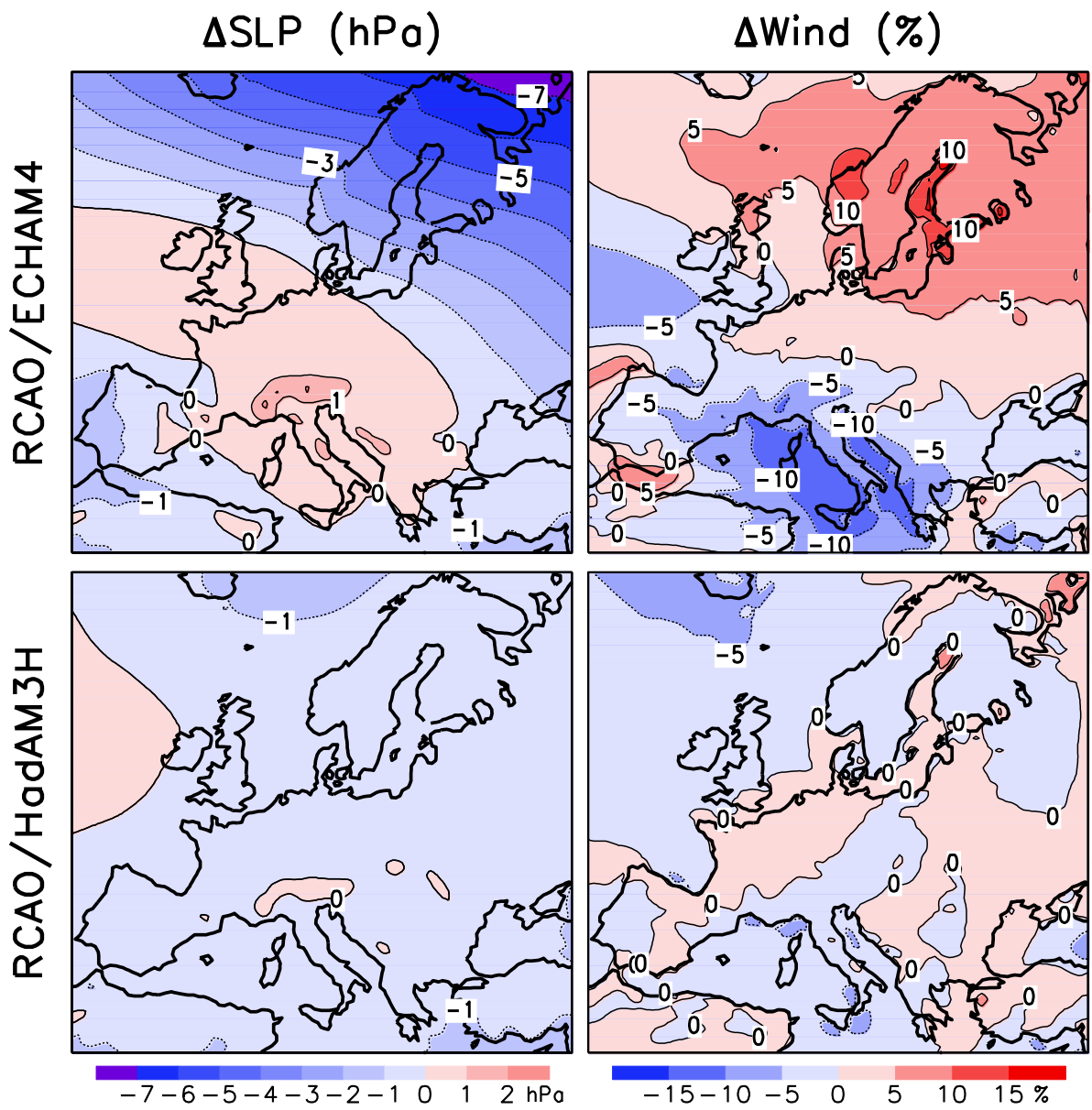

$1448 \quad$ Figure 5. Changes in annual mean sea level pressure (left) and wind speed (right) from

1449 the years 1961-1990 to 2071-2100. The results are based on the SRES A2 emissions

1450 scenario and were produced using the same RCM (Rossby Centre regional Atmosphere-

1451 Ocean model; RCAO) using boundary data from two GCMs: ECHAM4/OPYC3 (top) and

1452 HadAM3H (bottom). Redrawn from Räisänen et al. (2004). 

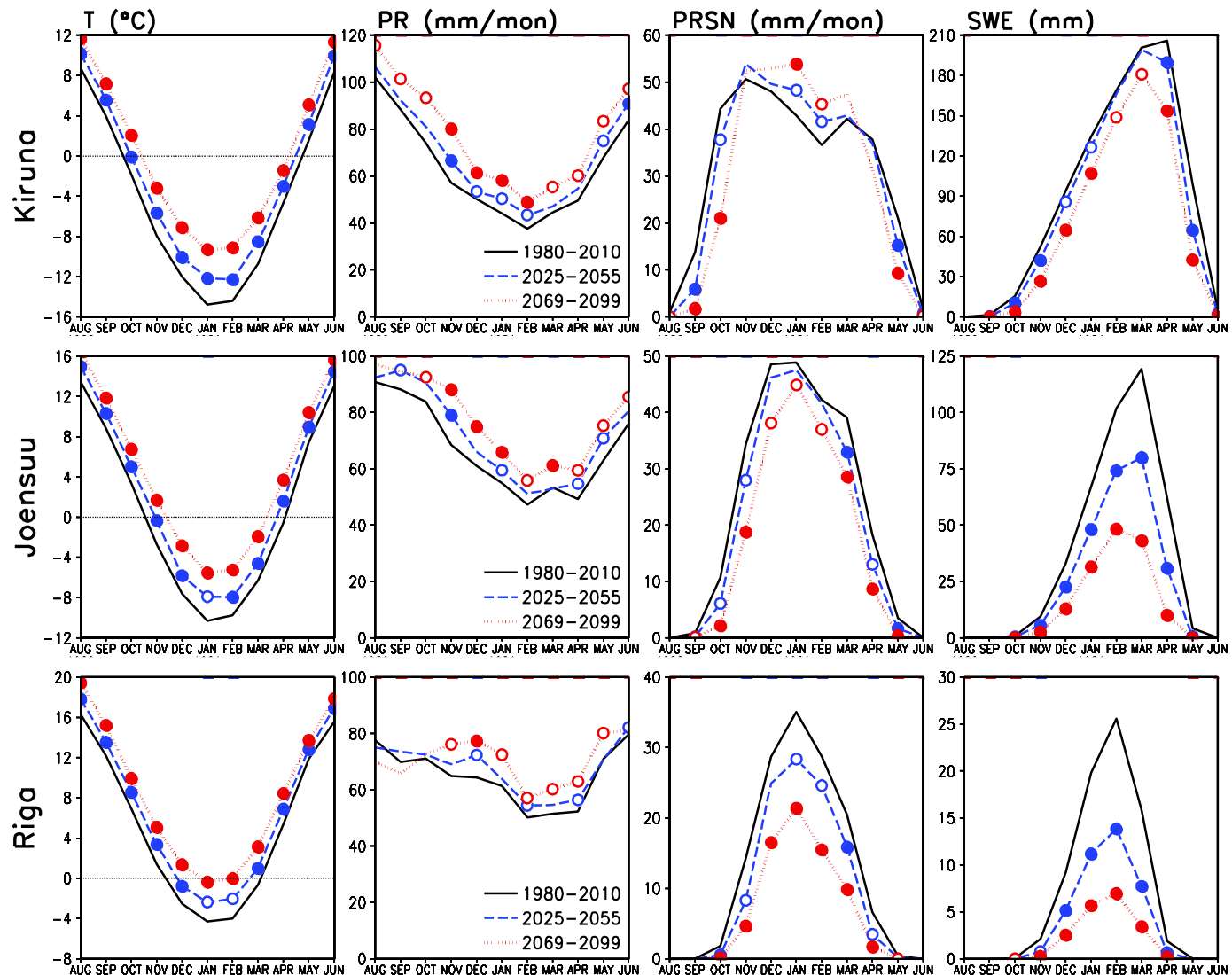

Figure 6. Simulated 30-year mean seasonal cycles (August to June) of temperature

1456 (T), precipitation (PR), snowfall (PRSN), and water equivalent of the snow pack

1457 (SWE) at three locations in the Baltic Sea basin: Kiruna in Swedish Lapland,

1458 Joensuu in eastern Finland, and Riga in Latvia. Black $=1980-2010$, blue $=2025$ -

14592055 , red $=2069-2099$. The figure is based on 12 RCM simulations from the

1460 ENSEMBLES project under the SRES A1B emissions scenario (Räisänen, 2015).

1461 Closed (open) circles indicate months in which all 12 (10 or 11) models agree on

1462 the sign of the change relative to 1980-2010. 


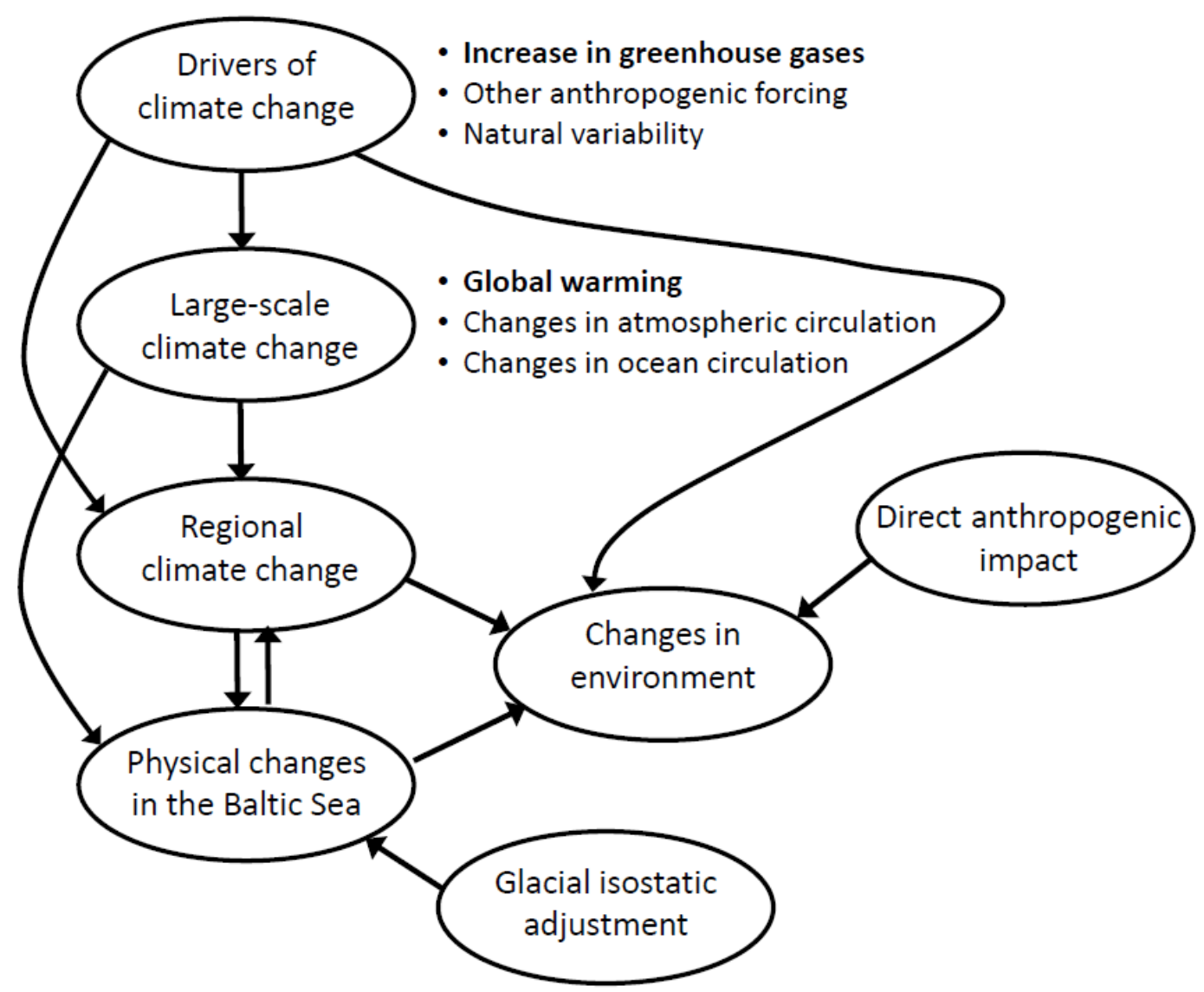

1465 Figure 7. A schematic overview of the main drivers and interactions that are expected to

1466 affect the climate and the environment in the Baltic Sea region in the $21^{\text {st }}$ century. The

1467 arrow from "Drivers of climate change" to "Regional climate change" refers to local

1468 climate forcings such as land use change. The arrows from "Large-scale climate

1469 change" and "Glacial isostatic adjustment" to "Physical changes in the Baltic Sea"

1470 refer to sea level change. 